\title{
Elemental analysis of chamber organic aerosol using an aerodyne high-resolution aerosol mass spectrometer
}

\author{
P. S. Chhabra ${ }^{1}$, R. C. Flagan ${ }^{1,2}$, and J. H. Seinfeld ${ }^{1,2}$ \\ ${ }^{1}$ Division of Chemistry and Chemical Engineering, California Institute of Technology, Pasadena, CA, USA \\ ${ }^{2}$ Division of Engineering and Applied Science, California Institute of Technology, Pasadena, CA, USA
}

Received: 3 December 2009 - Published in Atmos. Chem. Phys. Discuss.: 21 December 2009

Revised: 1 April 2010 - Accepted: 26 April 2010 - Published: 3 May 2010

\begin{abstract}
The elemental composition of laboratory chamber secondary organic aerosol (SOA) from glyoxal uptake, $\alpha$-pinene ozonolysis, isoprene photooxidation, single-ring aromatic photooxidation, and naphthalene photooxidation is evaluated using Aerodyne high-resolution time-of-flight mass spectrometer data. SOA $\mathrm{O} / \mathrm{C}$ ratios range from 1.13 for glyoxal uptake experiments to $0.30-0.43$ for $\alpha$-pinene ozonolysis. The elemental composition of $\alpha$-pinene and naphthalene SOA is also confirmed by offline mass spectrometry. The fraction of organic signal at $m / z 44$ is generally a good measure of SOA oxygenation for $\alpha$-pinene $/ \mathrm{O}_{3}$, isoprene/high- $\mathrm{NO}_{\mathrm{x}}$, and naphthalene $\mathrm{SOA}$ systems. The agreement between measured and estimated $\mathrm{O} / \mathrm{C}$ ratios tends to get closer as the fraction of organic signal at $\mathrm{m} / \mathrm{z} 44$ increases. This is in contrast to the glyoxal uptake system, in which $\mathrm{m} / \mathrm{z} 44$ substantially underpredicts O/C. Although chamber SOA has generally been considered less oxygenated than ambient SOA, single-ring aromatic- and naphthalenederived SOA can reach $\mathrm{O} / \mathrm{C}$ ratios upward of 0.7 , well within the range of ambient PMF component OOA, though still not as high as some ambient measurements. The spectra of aromatic and isoprene-high- $\mathrm{NO}_{\mathrm{x}} \mathrm{SOA}$ resemble that of OOA, but the spectrum of glyoxal uptake does not resemble that of any ambient organic aerosol PMF component.
\end{abstract}

\section{Introduction}

The chemical composition of secondary organic aerosol (SOA) from a volatile organic precursor comprises dozens of compounds owing to the variety of reaction pathways leading to semivolatile products (Hallquist et al., 2009; Kroll and Seinfeld, 2008). Offline analysis techniques can typi-

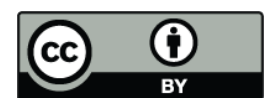

Correspondence to: J. H. Seinfeld (seinfeld@caltech.edu) cally quantify only a portion of the wide array of compounds present in SOA. Though generally not able to provide detailed composition profiles of organic aerosol (OA), bulk, real-time mass spectrometric analysis has become an indispensable tool in chemically characterizing OA. The widely used Aerodyne quadrupole aerosol mass spectrometer (QAMS) uses thermal vaporization followed by electron impact ionization and a quadrupole mass analyzer to quantify the non-refractory portion of sub-micron aerosol mass (Jayne et al., 2000; Jimenez et al., 2003; Canagaratna et al., 2007). The original Q-AMS has been updated to improve sensitivity and time resolution by replacing the quadrupole mass spectrometer with a compact time-of-flight mass spectrometer (C-ToF-AMS) (Drewnick et al., 2005). While the C-ToF-AMS does improve the mass resolution over the QAMS, it still does not effectively distinguish different ions with the same nominal mass. Large gains in mass resolution were achieved when a high-resolution time-of-flight mass spectrometer (H-TOF Series, Tofwerk, Thun, Switzerland) was combined with the original AMS design (HR-ToFAMS) (DeCarlo et al., 2006). The advantage of the HRToF-AMS is that it can distinguish and quantify ions with the same nominal mass but different elemental compositions, e.g. organic ions of the form, $\mathrm{C}_{\mathrm{x}} \mathrm{H}_{\mathrm{y}}{ }^{+}, \mathrm{C}_{\mathrm{x}} \mathrm{H}_{\mathrm{y}} \mathrm{O}_{\mathrm{z}}{ }^{+}, \mathrm{C}_{\mathrm{x}} \mathrm{H}_{\mathrm{y}} \mathrm{N}_{\mathrm{p}}{ }^{+}$, and $\mathrm{C}_{\mathrm{x}} \mathrm{H}_{\mathrm{y}} \mathrm{O}_{\mathrm{z}} \mathrm{N}_{\mathrm{p}}{ }^{+}$, allowing for a more detailed analysis of the elemental composition of SOA, and most importantly, its oxygen content.

DeCarlo et al. (2006) demonstrated the first application of a field-deployable HR-ToF-AMS during the MIRAGE and SOAR-1 field campaigns and found that the vast majority of the organic signal could be attributed to either $\mathrm{C}_{\mathrm{x}} \mathrm{H}_{\mathrm{y}}{ }^{+}$ or $\mathrm{C}_{\mathrm{x}} \mathrm{H}_{\mathrm{y}} \mathrm{O}_{\mathrm{z}}^{+}$ions. Aiken et al. (2007) further developed HR-ToF-AMS analysis by showing that elemental ratios of $\mathrm{OA}$, i.e. $\mathrm{O} / \mathrm{C}, \mathrm{H} / \mathrm{C}, \mathrm{N} / \mathrm{C}$ and $\mathrm{OM} / \mathrm{OC}$, could be estimated from the relative intensities of chemically identified ion fragments. The first detailed analyses of high-resolution data was from the MILAGRO campaign measuring ambient aerosol in

Published by Copernicus Publications on behalf of the European Geosciences Union. 
and around Mexico City (DeCarlo et al., 2008; Aiken et al., 2008, 2009). Aiken et al. (2008) demonstrated the first measurements of the elemental composition of ambient OA in this field campaign and showed that the $\mathrm{O} / \mathrm{C}$ ratios ranged from $0.06-0.10$ for primary organic aerosol (POA) to about 0.76 for the most oxidized aerosol. Aiken et al. (2008) also showed that the fraction of the $\mathrm{m} / \mathrm{z} 44$ signal to the total organic signal correlated well with $\mathrm{O} / \mathrm{C}$ ratio and found it to be a good surrogate for the oxygen content of OA. DeCarlo et al. (2008) found that O/C ratios were highest in nonurban (regional) locations and that $\mathrm{O} / \mathrm{C}$ could be a qualitative indicator of photochemical age. Aiken et al. (2008) performed the first positive matrix factorization (PMF) analysis on a HR-ToF-AMS data set from the MILAGRO campaign, finding that three components dominated OA: hydrocarbonlike organic aerosol ( $\mathrm{HOA}, \mathrm{Avg}$. $\mathrm{O} / \mathrm{C}=0.16$ ), oxygenated organic aerosol (OOA, Avg. $\mathrm{O} / \mathrm{C}=0.60)$ and biomass burning organic aerosol (BBOA, Avg. $\mathrm{O} / \mathrm{C}=0.30$ ). A fourth factor from a local source with non-negligible nitrogen content was also found (LOA, Avg. $\mathrm{O} / \mathrm{C}=0.13$ and $\mathrm{N} / \mathrm{C}=0.06$ ). Recently, aerosol measurements were made at the peak of Whistler Mountain during INTEX-B and the average O/C was 0.83 (Sun et al., 2009). Thermal denuder measurements of OA from SOAR-1 and MILAGRO campaigns with a HR-ToFAMS demonstrated that aerosol volatility was inversely correlated with O/C ratio (Huffman et al., 2009).

The first series of chamber laboratory experiments to which the HR-ToF-AMS elemental analysis was applied were of SOA generated from the photooxidation of $\alpha$-pinene, isoprene, toluene, and gasoline vapors and ozonolysis of $\alpha$ pinene. Analyzing data from these experiments, Aiken et al. (2008) concluded that chamber SOA, characterized by O/C ratios from $0.27-0.42$, was less oxidized than ambient OOA (at concentrations higher than ambient, as used to derive the previous generation of SOA models). For $\alpha$-pinene ozonolysis SOA, Shilling et al. (2009) demonstrated that the O/C ratio increased as aerosol loadings decreased, and at the lowest loadings, the mass spectrum resembled that of ambient OOA. Further work on the same system showed that a product specific volatility model could predict measured $\mathrm{O} / \mathrm{C}$ ratios but overpredicted H/C ratios (Chan et al., 2009b). Mohr et al. (2009) also used the HR-ToF-AMS to measure the degree of oxygenation of POA from meat cooking, trash burning, and vehicle exhaust and concluded that emissions from such sources could not be a substantial source of ambient OOA. Other chamber studies have used the HR-ToF-AMS to study the chemical mechanism of SOA formation from specific precursors, such as glyoxal, naphthalene, and amines (Galloway et al., 2009; Chan et al., 2009a; Kautzman et al., 2010; Malloy et al., 2009). Most recently, the HR-ToFAMS has been used to study the heterogeneous $\mathrm{OH}$ oxidation of squalane particles to infer the mechanisms of OA aging (Smith et al., 2009; Kroll et al., 2009).

Ambient studies with the HR-ToF-AMS infer that much of the oxygenation of OA occurs as a result of photochem- ical aging of SOA, with the highest $\mathrm{O} / \mathrm{C}$ ratios measured in remote regions. PMF analysis of HR-ToF-AMS data identifies similar components to those found from unit mass resolution data (Ulbrich et al., 2009; Zhang et al., 2005a,b, 2007; Lanz et al., 2007), the most common factors being HOA and OOA, which has been further subcategorized into lowvolatility OOA (LV-OOA, previously known as OOA-1) and semi-volatile OOA (SV-OOA, previously known as OOA2) (Jimenez et al., 2009). LV-OOA has been characterized as aged OOA, having $\mathrm{O} / \mathrm{C}$ ratios of at least 0.6 across most ambient data sets and spectra dominated by mass fragment $\mathrm{CO}_{2}{ }^{+}$at $\mathrm{m} / \mathrm{z}$ 44. Chamber SOA, however, generally does not exhibit as large $\mathrm{O} / \mathrm{C}$ ratios as $\mathrm{LV}-\mathrm{OOA}$, at most reaching $\mathrm{O} / \mathrm{C}$ ratios of SV-OOA and producing spectra with $\mathrm{C}_{2} \mathrm{H}_{3} \mathrm{O}^{+}$ at $\mathrm{m} / \mathrm{z} 43$ as the dominant ion. In chamber investigations that use high precursor concentrations to generate SOA at aerosol loadings much higher than that of ambient OA, less oxygenated species partition into the particle phase. Additionally, chamber experiments are typically run for $<24 \mathrm{~h}$, which, while adequate to produce SOA from the photooxidation or ozonolysis of most SOA precursors, is still shorter than the atmospheric lifetime ( $\sim 1$ week) of ambient aerosol. Despite these limitations, chamber experiments are crucial to constraining SOA models and providing insight into the mechanisms involved in the formation and evolution of SOA (Kroll and Seinfeld, 2008). While comprehensive chamber studies of many different VOCs with the Q-AMS have been conducted (Bahreini et al., 2005), it has generally not been possible to directly compare offline speciation data to AMS data. The HR-ToF-AMS now provides the unique opportunity to make direct comparisons to offline speciation.

In this study we evaluate HR-ToF-AMS data on the elemental composition of chamber OA from a comprehensive suite of SOA systems: glyoxal uptake, $\alpha$-pinene ozonolysis, isoprene photooxidation, single-ring aromatic photooxidation, and naphthalene photooxidation. We compare our findings to other laboratory composition studies and identify discrepancies and sources of uncertainty. In addition, we evaluate the use of $m / z 44$ as a surrogate for OA oxygenation. Lastly, we compare the elemental ratios measured in the chamber to those measured in ambient OA and derived from PMF analysis.

\section{Experimental section}

\subsection{Chamber operation}

All of the experiments analyzed here (Table 1) were performed in Caltech's dual $28 \mathrm{~m}^{3}$ Teflon environmental chambers (Cocker et al., 2001; Keywood et al., 2004) over the period 2007-2009. Before each experiment, the chambers were flushed for $>24 \mathrm{~h}$ until the particle number concentration was $<100 \mathrm{~cm}^{3}$ and the volume concentration was $<0.1 \mathrm{~cm}^{3} \mathrm{~m}^{-3}$. Each chamber has a dedicated Differential 
Table 1. Experimental conditions and results.

\begin{tabular}{|c|c|c|c|c|c|c|c|c|}
\hline Expt.\# & VOC System & Experiment Type & $\begin{array}{l}\mathrm{RH} \\
(\%)\end{array}$ & $\begin{array}{r}{[\mathrm{NO}]_{0}} \\
(\mathrm{ppb})\end{array}$ & $\begin{array}{r}{\left[\mathrm{NO}_{2}\right]_{0}} \\
(\mathrm{ppb})\end{array}$ & $\begin{array}{r}\text { VOC Reacted } \\
(\mathrm{ppb})\end{array}$ & $\begin{array}{r}\text { Seed Vol. } \\
\left(\mu \mathrm{m}^{3} \mathrm{~cm}^{-3}\right)\end{array}$ & $\begin{array}{r}\Delta M_{0}(\operatorname{Max})^{d} \\
\left(\mu \mathrm{g} \mathrm{m}^{-3}\right)\end{array}$ \\
\hline 1 & glyoxal uptake & humid & 67 & $<\operatorname{det}^{\mathrm{a}}$ & $<5$ & $131^{\mathrm{b}}$ & 84 & 31.80 \\
\hline 2 & glyoxal uptake & humid & 60 & $<\operatorname{det}^{\mathrm{a}}$ & $<\operatorname{det}^{\mathrm{a}}$ & $182^{\mathrm{b}}$ & 87 & 68.30 \\
\hline 3 & glyoxal uptake & humid & 70 & $<\operatorname{det}^{\mathrm{a}}$ & $<\operatorname{det}^{\mathrm{a}}$ & NA & NA & NA \\
\hline 4 & $\alpha$-pinene $+\mathrm{O}_{3}$ & no $\mathrm{H}_{2} \mathrm{O}_{2}$, dry & 5.4 & $<\operatorname{det}^{\mathrm{a}}$ & $<\operatorname{det}^{\mathrm{a}}$ & $50^{\mathrm{c}}$ & 12.45 & 56.84 \\
\hline 5 & $\alpha$-pinene $+\mathrm{O}_{3}$ & no $\mathrm{H}_{2} \mathrm{O}_{2}$, humid & 66 & $<\operatorname{det}^{\mathrm{a}}$ & $<\operatorname{det}^{\mathrm{a}}$ & $50^{\mathrm{c}}$ & 20.00 & 83.30 \\
\hline 6 & $\alpha$-pinene $+\mathrm{O}_{3}$ & $\mathrm{H}_{2} \mathrm{O}_{2}$, dry & 7.2 & $<\operatorname{det}^{\mathrm{a}}$ & $<\operatorname{det}^{\mathrm{a}}$ & $50^{\mathrm{c}}$ & 11.59 & 121.00 \\
\hline 7 & $\alpha$-pinene $+\mathrm{O}_{3}$ & $\mathrm{H}_{2} \mathrm{O}_{2}$, humid & 72.3 & $<\operatorname{det}^{\mathrm{a}}$ & $<\operatorname{det}^{\mathrm{a}}$ & $50^{\mathrm{c}}$ & 27.38 & 183.22 \\
\hline 8 & isoprene $+\mathrm{OH}$ & low-NO $\mathrm{NO}_{\mathrm{x}}$ & 5.2 & $<\operatorname{det}^{\mathrm{a}}$ & $<\operatorname{det}^{\mathrm{a}}$ & 49 & 16.23 & 3.71 \\
\hline 9 & isoprene $+\mathrm{OH}$ & low- $\mathrm{NO}_{\mathrm{X}}$ & 5.3 & $<\operatorname{det}^{\mathrm{a}}$ & $<\operatorname{det}^{\mathrm{a}}$ & 49 & NA & 7.00 \\
\hline 10 & isoprene $+\mathrm{OH}$ & lowNO ${ }_{\mathrm{x}}$ & $<10$ & $<\operatorname{det}^{\mathrm{a}}$ & $<\operatorname{det}^{\mathrm{a}}$ & 91 & 10.54 & 10.47 \\
\hline 11 & isoprene $+\mathrm{OH}$ & high- $\mathrm{NO}_{\mathrm{x}}$ & $<10$ & 518 & 374 & 81 & 11.00 & 1.35 \\
\hline 12 & isoprene $+\mathrm{OH}$ & high- $\mathrm{NO}_{\mathrm{x}}$ & $<10$ & 536 & 400 & 267 & 11.73 & 4.27 \\
\hline 13 & isoprene $+\mathrm{OH}$ & high- $\mathrm{NO}_{\mathrm{x}}$ & $<10$ & 591 & 434 & 286 & 13.80 & 11.83 \\
\hline 14 & toluene $+\mathrm{OH}$ & low- $\mathrm{NO}_{\mathrm{x}}$ & $<10$ & $<\operatorname{det}^{\mathrm{a}}$ & $<\operatorname{det}^{\mathrm{a}}$ & 112 & 10.86 & 141.45 \\
\hline 15 & toluene $+\mathrm{OH}$ & high- $\mathrm{NO}_{\mathrm{x}}$ & $<10$ & 583 & 423 & 136 & 9.32 & 50.26 \\
\hline 16 & $m$-xylene $+\mathrm{OH}$ & low- $\mathrm{NO}_{\mathrm{x}}$ & $<10$ & $<\operatorname{det}^{\mathrm{a}}$ & $<\operatorname{det}^{\mathrm{a}}$ & 114 & 9.78 & 190.40 \\
\hline 17 & $m$-xylene $+\mathrm{OH}$ & high- $\mathrm{NO}_{\mathrm{x}}$ & $<10$ & 501 & 538 & 200 & 9.34 & 52.04 \\
\hline 18 & naphthalene $+\mathrm{OH}$ & low- $\mathrm{NO}_{\mathrm{x}}$ & 7.8 & $<\operatorname{det}^{\mathrm{a}}$ & $<\operatorname{det}^{\mathrm{a}}$ & $5^{\mathrm{c}}$ & 10.64 & 12.15 \\
\hline 19 & naphthalene $+\mathrm{OH}$ & low- $\mathrm{NO}_{\mathrm{X}}$ & 13.9 & $<\operatorname{det}^{\mathrm{a}}$ & $<\operatorname{det}^{\mathrm{a}}$ & 12 & 24.52 & 44.91 \\
\hline 20 & naphthalene $+\mathrm{OH}$ & low- $\mathrm{NO}_{\mathrm{X}}$, nucleation & 8.1 & $<\operatorname{det}^{\mathrm{a}}$ & $<\operatorname{det}^{\mathrm{a}}$ & $15^{\mathrm{c}}$ & 0.00 & 47.17 \\
\hline 21 & naphthalene $+\mathrm{OH}$ & low- $\mathrm{NO}_{\mathrm{x}}$ & 8.3 & $<\operatorname{det}^{\mathrm{a}}$ & $<\operatorname{det}^{\mathrm{a}}$ & $20^{\mathrm{c}}$ & 10.48 & 53.12 \\
\hline 22 & naphthalene $+\mathrm{OH}$ & low- $\mathrm{NO}_{\mathrm{X}}$ & 9.9 & $<\operatorname{det}^{\mathrm{a}}$ & $<\operatorname{det}^{\mathrm{a}}$ & 63 & 12.98 & 201.75 \\
\hline 23 & naphthalene $+\mathrm{OH}$ & high- $\mathrm{NO}_{\mathrm{x}}$ & 7.7 & 415 & 272 & $5^{c}$ & 12.25 & 5.90 \\
\hline 24 & naphthalene $+\mathrm{OH}$ & high- $\mathrm{NO}_{\mathrm{x}}$ & 6.3 & 431 & 370 & $25^{\mathrm{c}}$ & 12.82 & 39.02 \\
\hline 25 & naphthalene $+\mathrm{OH}$ & high- $\mathrm{NO}_{\mathrm{x}}$, nucleation & $<10$ & 422 & 222 & $350^{\mathrm{c}}$ & 0.00 & 39.26 \\
\hline 26 & naphthalene $+\mathrm{OH}$ & high- $\mathrm{NO}_{\mathrm{x}}$ & 5.9 & 401 & 166 & 40 & 14.67 & 75.43 \\
\hline
\end{tabular}

a Below the detection limit of the measurement

${ }^{\mathrm{b}}$ Equilibrium concentration

c Approximate initial concentration

${ }^{\mathrm{d}}$ Mass loadings are calculated by multiplying the change in DMA volume by an estimated density. Estimated densities of glyoxal, $\alpha$-pinene, isoprene, single-ringed aromatics, and naphthalene SOA were taken from Galloway et al. (2009); Bahreini et al. (2005); Kroll et al. (2006); $\mathrm{Ng}$ et al. (2007); Chan et al. (2009a), respectively.

Mobility Analyzer (DMA, TSI model 3081) coupled with a condensation nucleus counter (TSI model 3760) for measuring aerosol size distribution and number and volume concentration. Temperature, relative humidity $(\mathrm{RH})$, ozone $\left(\mathrm{O}_{3}\right)$, $\mathrm{NO}$, and $\mathrm{NO}_{\mathrm{x}}$ were continuously monitored. For seeded experiments, ammonium sulfate seed particles were generated by atomization of a dilute aqueous ammonium sulfate solution using a constant rate atomizer.

For the experiments involving glyoxal, glyoxal preparation and experimental design are described by Galloway et al. (2009). Briefly, glyoxal uptake experiments begin by introducing gas-phase glyoxal into a dark, humid chamber and allowing the concentration to equilibrate over about $10 \mathrm{~h}$. Approximately $160 \mathrm{ppb}$ of cyclohexane was also added as a tracer for dilution. Once the gas-phase glyoxal concentration reached a steady state, ammonium sulfate seed aerosol, existing as a metastable solution, was introduced and the resulting organic growth was monitored by both the DMA and
HR-ToF-AMS. After organic growth leveled off, the chamber air mass was diluted with clean hydrocarbon-free air to investigate the reversibility of uptake. The amount of dilution was calculated by monitoring the cyclohexane concentration with a gas-chromatograph with flame ionization detector (GC-FID, Agilent 6890N).

Ozonolysis experiments are described by Chan et al. (2009b). The effect of humidity and $\mathrm{H}_{2} \mathrm{O}_{2}$ on SOA formation were tested and permutated in the four experiments. The parent hydrocarbon, $\alpha$-pinene (50 ppb), and an $\mathrm{OH}$ scavenger, cyclohexane, were introduced separately by injecting known volumes of the liquid hydrocarbon into a glass bulb, subsequently carried into the chamber by an air stream at $5 \mathrm{~L} \mathrm{~min}^{-1}$. The estimated mixing ratio of cyclohexane was $37 \mathrm{ppm}$, at which the rate of cyclohexane $+\mathrm{OH}$ exceeds that of $\alpha$-pinene $+\mathrm{OH}$ by a factor of $100 . \mathrm{O}_{3}$ injection was stopped after the $\mathrm{O}_{3}$ concentration reached $180 \mathrm{ppb}$. 
The protocol for isoprene (Kroll et al., 2006), single-ring aromatic (Ng et al., 2007), and naphthalene (Chan et al., 2009a) photooxidation experiments are described in detail in the references cited. For high- $\mathrm{NO}_{\mathrm{x}}$ experiments (initial $[\mathrm{NO}]>300 \mathrm{ppb}$ ), nitrous acid (HONO) was used as an $\mathrm{OH}$ source, at amounts between 175 and $310 \mathrm{ppb}$. Additional NO was added until the total NO mixing ratio was about $400-500 \mathrm{ppb}$. For low- $\mathrm{NO}_{\mathrm{x}}$ experiments, hydrogen peroxide $\left(\mathrm{H}_{2} \mathrm{O}_{2}\right)$ was used as an $\mathrm{OH}$ source.

\subsection{High-resolution time-of-flight aerosol mass spectrometer}

In all of the experiments considered here, real-time particle mass spectra were collected continuously by a HR-ToFAMS, henceforth referred to as the AMS (Canagaratna et al., 2007; DeCarlo et al., 2006). In the mode of operation, the AMS was switched once every minute between the highresolution "W-mode" and the lower resolution, higher sensitivity "V-mode". The "V-mode" data were analyzed using a fragmentation table to separate sulfate, ammonium, and organic spectra and to time-trace specific mass-to-charge ratios (Allan et al., 2004). "W-mode" data were analyzed using a separate high-resolution spectra toolbox known as PIKA to determine the chemical formulas contributing to distinct mass-to-charge $(\mathrm{m} / \mathrm{z}$ ) ratios (DeCarlo et al., 2006).

The AMS elemental analysis procedure exploits the properties of electron impact (EI) ionization to determine the elemental composition of OA (Aiken et al., 2007). Briefly, the signal generated from the measured ion fragments of EI ionization is approximately proportional to the mass concentration of the initial species (Jimenez et al., 2003; Crable and Coggeshall, 1958). Because high-resolution mass spectra can determine the chemical formula of each ion fragment, the average elemental composition of all ions can be calculated. Thus the relative mass concentration $M_{X}$ of a given element $X$ is computed as follows:

$M_{X}=\sum_{i=m / z_{\min }}^{m / z_{\max }} I_{i} \frac{m_{X}}{m_{i}}$

where $I_{i}$ is the ion signal at fragment $i, m_{X}$ is the atomic mass of element $X$, and $m_{i}$ is the mass of singly charged fragment ion $i$. The elemental ratio $X / Y$ is then

$X / Y=\alpha_{X / Y} \frac{\frac{M_{X}}{m_{X}}}{\frac{M_{Y}}{m_{Y}}}$

where $\alpha_{X / Y}$ is the calibration factor for that particular ratio, determined by laboratory samples with known elemental compositions. The organic mass to organic carbon ratio $\mathrm{OM} / \mathrm{OC}$ ratio is calculated as follows

$\mathrm{OM} / \mathrm{OC}=\frac{12+(16 \times \mathrm{O} / \mathrm{C})+(1 \times \mathrm{H} / \mathrm{C})+(14 \times \mathrm{N} / \mathrm{C})+\ldots}{12}$
Aiken et al. (2007, 2008) sampled 59 different standards with the HR-ToF-AMS and determined calibration factors for $\mathrm{O} / \mathrm{C}, \mathrm{H} / \mathrm{C}$, and $\mathrm{N} / \mathrm{C}$ and estimated uncertainties for each ratio as shown in Supplemental Table S2 (http://www.atmos-chem-phys.net/10/4111/2010/ acp-10-4111-2010-supplement.pdf). O/C, H/C, N/C and $\mathrm{OM} / \mathrm{OC}$ ratios in the present study were computed using the computation toolbox "Analytical Procedure for Elemental Separation" (APES), which applies the analysis procedure as described by Aiken et al. $(2007,2008)$ to the W-mode data.

$\mathrm{O} / \mathrm{C}$ ratios were also estimated from $\mathrm{V}$-mode data using the organic signal at $\mathrm{m} / z 44$ (with gas-phase $\mathrm{CO}_{2}$ signal removed) as a surrogate for oxygenation in OA. Typically, the $\mathrm{m} / \mathrm{z} 44$ signal arises from $\mathrm{CO}_{2}{ }^{+}$ions, which are commonly formed from the fragmentation of carboxylic acids (Takegawa et al., 2007). Aiken et al. (2008) correlated the fraction of organic signal at $\mathrm{m} / \mathrm{z} 44$ to the $\mathrm{O} / \mathrm{C}$ ratio determined from high-resolution analysis and derived the following empirical relationship based on Mexico City data

$\mathrm{O} / \mathrm{C}_{44}=3.82 \times \mathrm{f}_{44}+0.0794$

where $\mathrm{O} / \mathrm{C}_{44}$ is the estimated $\mathrm{O} / \mathrm{C}$ ratio using $\mathrm{m} / \mathrm{z} 44$ as a surrogate and $\mathrm{f}_{44}$ is the organic signal at $\mathrm{m} / \mathrm{z} 44$ divided by the total organic signal. V-mode data were chosen for the $\mathrm{O} / \mathrm{C}$ estimation so as to maximize the signal to noise in the calculation; W-mode data could have been used for the O/C estimation for experiments that were not signal limited. Comparisons of $\mathrm{f}_{44}$ between both modes of operation produced little difference across all systems that were studied. The $\mathrm{O} / \mathrm{C}$ ratio calculated from $\mathrm{m} / \mathrm{z}, 44$ from $\mathrm{V}$-mode data will be referred to as $\mathrm{O} / \mathrm{C}_{44}$, and the $\mathrm{O} / \mathrm{C}$ ratio determined from $\mathrm{W}$ mode data in APES will be referred to as $\mathrm{O} / \mathrm{C}_{\mathrm{HR}}$ when the two are compared.

APES allows for special treatment of ions that may have contamination from air and allows users to include "ion families" that are traditionally considered fragments of inorganic species as part of the organic mass. The $\mathrm{CO}_{2}{ }^{+}$signal originating from ambient air $\mathrm{CO}_{2}$ is removed to determine the organic contribution of $\mathrm{CO}_{2}{ }^{+}$to $\mathrm{m} / z$ 44. Fourier transform infrared spectroscopy measurements show the concentration of $\mathrm{CO}_{2}$ in the chamber air is nominally the same as in the atmosphere, estimated to be $370 \mathrm{ppm}$. The ion $\mathrm{CO}^{+}(\mathrm{m} / \mathrm{z} 28)$ signal, another common fragment of organic species, tends to be overwhelmed by $\mathrm{N}_{2}{ }^{+}$from $\mathrm{N}_{2}$ in ambient air. As a result, the contribution of $\mathrm{CO}^{+}$to the total organic signal is usually estimated as a factor of the $\mathrm{CO}_{2}{ }^{+}$organic signal. The ratios of the particle-phase signals of $\mathrm{CO}^{+}$to $\mathrm{CO}_{2}{ }^{+}$are listed in Supplemental Table S3 (http://www.atmos-chem-phys.net/ 10/4111/2010/acp-10-4111-2010-supplement.pdf) and were determined from HR spectra of experiments in which the OA loading is high, for all systems except isoprene photooxidation, for which the default ratio was used. The signals from $\mathrm{H}_{2} \mathrm{O}^{+}, \mathrm{OH}^{+}$, and $\mathrm{O}^{+}$in the particulate organic mass may suffer interference from gas-phase $\mathrm{H}_{2} \mathrm{O}$, and their organic contributions are estimated as suggested in Aiken et al. 
Table 2. Elemental composition of each SOA system. Values represent the average ratio for each experiment at the time of maximum O/C. Uncertainty estimates reflect the measurement uncertainty as determined by Aiken et al. (2008).

\begin{tabular}{|c|c|c|c|c|c|}
\hline VOC System & & $\mathrm{O} / \mathrm{C}(\max )$ & $\mathrm{H} / \mathrm{C}$ & $\mathrm{N} / \mathrm{C}$ & $\mathrm{OM} / \mathrm{OC}$ \\
\hline glyoxal uptake & & $1.13 \pm 0.35$ & $1.54 \pm 0.15$ & $0.01 \pm 0.0022$ & $2.68 \pm 0.16$ \\
\hline$\alpha$-pinene $+\mathrm{O}_{3}$ & & $0.43 \pm 0.13$ & $1.47 \pm 0.15$ & $0.00 \pm 0$ & $1.70 \pm 0.10$ \\
\hline isoprene $+\mathrm{OH}$ & & $0.61 \pm 0.19$ & $1.55 \pm 0.16$ & $0.02 \pm 0.0044$ & $1.96 \pm 0.12$ \\
\hline \multirow{5}{*}{ aromatics $+\mathrm{OH}$} & low- $\mathrm{NO}_{\mathrm{x}}$ & $0.59 \pm 0.18$ & $1.64 \pm 0.16$ & $0.00 \pm 0$ & $1.92 \pm 0.12$ \\
\hline & high- $\mathrm{NO}_{\mathrm{x}}$ & $0.62 \pm 0.19$ & $1.46 \pm 0.15$ & $0.04 \pm 0.0088$ & $2.00 \pm 0.12$ \\
\hline & & $0.68 \pm 0.21$ & $1.44 \pm 0.14$ & $0.04 \pm 0.0088$ & $2.07 \pm 0.12$ \\
\hline & $m$-xylene, high- $\mathrm{NO}_{\mathrm{x}}$ & $0.66 \pm 0.20$ & $1.48 \pm 0.15$ & $0.08 \pm 0.017$ & $2.09 \pm 0.13$ \\
\hline & $m$-xylene, low-NO $\mathrm{NO}_{\mathrm{x}}$ & $0.60 \pm 0.19$ & $1.54 \pm 0.15$ & $0.00 \pm 0$ & $1.93 \pm 0.12$ \\
\hline \multirow{5}{*}{ naphthalene $+\mathrm{OH}$} & toluene, high- $\mathrm{NO}_{\mathrm{x}}$ & $0.72 \pm 0.22$ & $1.38 \pm 0.14$ & $0.07 \pm 0.14$ & $2.15 \pm 0.13$ \\
\hline & toluene, low- $\mathrm{NO}_{\mathrm{x}}$ & $0.74 \pm 0.23$ & $1.39 \pm 0.14$ & $0.00 \pm 0$ & $2.10 \pm 0.13$ \\
\hline & & $0.62 \pm 0.19$ & $0.89 \pm 0.09$ & $0.02 \pm 0.0044$ & $1.93 \pm 0.12$ \\
\hline & low-NO $\mathrm{NO}_{\mathrm{x}}$ & $0.66 \pm 0.20$ & $0.88 \pm 0.09$ & $0.00 \pm 0$ & $1.96 \pm 0.12$ \\
\hline & high- $\mathrm{NO}_{\mathrm{x}}$ & $0.57 \pm 0.18$ & $0.90 \pm 0.09$ & $0.04 \pm 0.0088$ & $1.89 \pm 0.11$ \\
\hline
\end{tabular}

(2008). For all experiments, ions in the "OH family" that are not $\mathrm{H}_{2} \mathrm{O}^{+}, \mathrm{OH}^{+}$, and $\mathrm{O}^{+}$are added as part of the organic mass; however, their inclusion turns out to be negligible to the $\mathrm{O} / \mathrm{C}$ and $\mathrm{H} / \mathrm{C}$ calculations.

Particulate nitrogen signals were observed in high- $\mathrm{NO}_{\mathrm{x}}$ photooxidation experiments, mostly originating from $\mathrm{NO}^{+}$ and $\mathrm{NO}_{2}{ }^{+}$ions. In ambient studies, these ions usually result from the fragmentation of inorganic nitrates in the particle phase. Although gas-phase nitric acid is produced from the $\mathrm{OH}+\mathrm{NO}_{2}$ reaction, at low chamber humidities, nitric acid is not expected to partition appreciably into the particle phase. Thus, the signals of $\mathrm{NO}^{+}$and $\mathrm{NO}_{2}{ }^{+}$ions, termed as "NO Family" ions, are included as part of the organic mass in high- $\mathrm{NO}_{\mathrm{x}}$ photooxidation experiments to estimate the contribution of nitrogen from organonitrate compounds.

\section{Results}

Table 2 lists the average elemental ratios and estimated uncertainties at the time of the peak O/C ratio for each experimental system. Aerosol produced from glyoxal uptake exhibits the largest average $\mathrm{O} / \mathrm{C}$ and $\mathrm{OM} / \mathrm{OC}$ at 1.13 and 2.68, respectively, and $\alpha$-pinene- $\mathrm{O}_{3}$ SOA has the smallest average $\mathrm{O} / \mathrm{C}$ and $\mathrm{OM} / \mathrm{OC}$ at 0.43 and 1.70 , respectively. SOA from all $\mathrm{OH}$-photooxidation experiments exhibits intermediate $\mathrm{O} / \mathrm{C}$ and $\mathrm{OM} / \mathrm{OC}$ values ranging from 0.57 to 0.74 and 1.89 to 2.15 . Values of $\mathrm{N} / \mathrm{C}$ are essentially zero for low- $\mathrm{NO}_{\mathrm{x}}$ experiments and do not exceed 0.08 for high- $\mathrm{NO}_{\mathrm{x}}$ experiments. Values of $\mathrm{H} / \mathrm{C}$ vary from 1.39 to 1.64 for all systems except naphthalene-OH, which is 0.89 on average. Time trends of $\mathrm{O} / \mathrm{C}, \mathrm{H} / \mathrm{C}$ and $\mathrm{OM} / \mathrm{OC}$ ratios for systems with the same VOC and $\mathrm{NO}_{\mathrm{x}}$ conditions largely overlap, illustrating that elemental ratios tend to be a function of the extent of conversion of the parent hydrocarbon. OM/OC follows the same time dependence as $\mathrm{O} / \mathrm{C}$, as oxygen is the only major source of SOA mass other than carbon.

\subsection{SOA from reactive uptake of glyoxal}

Recently, glyoxal has received attention as being a possible ambient SOA precursor. It has been estimated that glyoxal could contribute to at least $15 \%$ of the SOA formation in Mexico City (Volkamer et al., 2007) and has been implicated in SOA formation from the photooxidation of acetylene (Volkamer et al., 2009). As we will show, the O/C ratio of glyoxal-SOA determined in the laboratory is the largest of any system we consider. Dzepina et al. (2009) modelled SOA formation in Mexico City, including glyoxal SOA, as well as updated aromatic SOA yields and SOA from primary semivolatile and intermediate volatility species. To evaluate the model, they compared the predicted $\mathrm{O} / \mathrm{C}$ ratios to those measured in Mexico City; assuming an $\mathrm{O} / \mathrm{C}$ ratio of 0.37 for aromatic SOA (Aiken et al., 2008), the model underpredicts the oxygen content of the ambient aerosol. When glyoxal is included as an SOA constituent and assumed to have an O/C of 1.0, the modelled SOA O/C is in much closer agreement with ambient measurements (while the assumed $\mathrm{O} / \mathrm{C}$ of glyoxal is close to what we will report below, the $\mathrm{O} / \mathrm{C}$ assumed for aromatic SOA is considerably lower than that measured).

Figure 1 displays the time dependence of $\mathrm{OM} / \mathrm{OC}, \mathrm{H} / \mathrm{C}$, $\mathrm{O} / \mathrm{C}$, and N/C ratios during the three glyoxal uptake experiments. At the onset of uptake, $\mathrm{O} / \mathrm{C}$ and $\mathrm{OM} / \mathrm{OC}$ rise sharply, reaching values of 1.13 and 2.68, respectively, the largest of these ratios of all the systems studied. This is not unexpected as pure glyoxal itself has an $\mathrm{O} / \mathrm{C}$ of 1 and $\mathrm{OM} / \mathrm{OC}$ of 2.42 , the highest of all the VOCs investigated. In aqueous solution, the two aldehyde groups of glyoxal can be hydrated, adding two $\mathrm{H}_{2} \mathrm{O}$ molecules. Also, glyoxal can polymerize to aldols and acetals, removing $\mathrm{H}_{2} \mathrm{O}$ (Whipple, 1970; Fratzke and Reilly, 


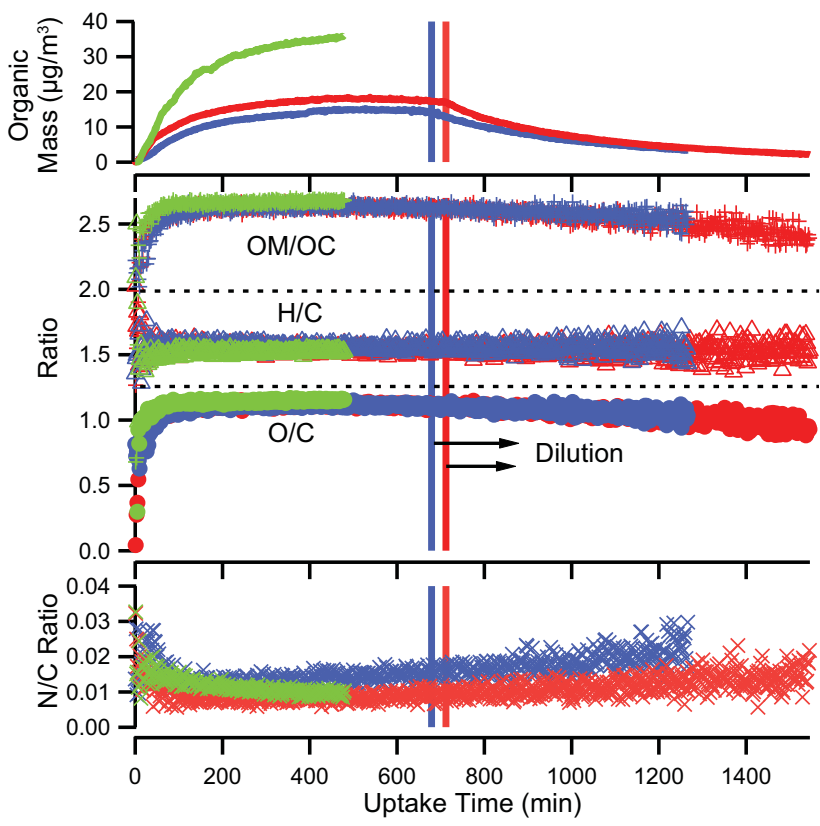

Fig. 1. Experimental profile of AMS organic mass (not corrected for collection efficiency), elemental ratios and $\mathrm{OM} / \mathrm{OC}$ for glyoxal uptake experiments. Experiment 1 is in blue, 2 in red and 3 in green. Dotted lines are provided to visually separate different ratios.

1986; Loeffler et al., 2006). Thus, the O/C of aqueous-phase glyoxal can be as high as $2, \mathrm{H} / \mathrm{C}$ as high as 3 , and OM/OC as high as 3.92. The measured ratios lay between these bounds, suggesting that both hydration and polymerization processes are occurring in the wet ammonium sulfate seed.

One can estimate the extent of polymerization based on the elemental composition measured by the AMS. Assuming that free glyoxal in the particle phase is hydrated twice, $\mathrm{C}_{2} \mathrm{H}_{2} \mathrm{O}_{2} \cdot 2 \mathrm{H}_{2} \mathrm{O}$, and that oligomerization produces straight chain acetals, for every monomer unit added to the chain, two water molecules are lost. Thus, a glyoxal oligomer will have the formula $\mathrm{C}_{2 n} \mathrm{O}_{2 n+2} \mathrm{H}_{2 n+4}$ where $n$ is the number of glyoxal subunits. On this basis, one gets $\mathrm{O} / \mathrm{C}=(n+1) / n$, $\mathrm{H} / \mathrm{C}=(n+2) / n$, and $\mathrm{OM} / \mathrm{OC}=(29 n+18) / 12 n$. Using the elemental values in Table 2 and solving for $n$, the number of glyoxal subunits ranges from 4 to 8 . Kua et al. (2008) performed DFT calculations to study the aqueous phase hydration and oligomerization of glyoxal and found that the dioxolane ring dimer $\left(\mathrm{C}_{4} \mathrm{H}_{8} \mathrm{O}_{6}, \mathrm{O} / \mathrm{C}=1.5\right.$, $\mathrm{H} / \mathrm{C}=2, \mathrm{OM} / \mathrm{OC}=3.2$ ) is the preferred thermodynamic form for oligomerization and that the hydrated trimer $\left(\mathrm{C}_{6} \mathrm{H}_{10} \mathrm{O}_{8}\right.$, $\mathrm{O} / \mathrm{C}=1.3, \mathrm{H} / \mathrm{C}=1.7, \mathrm{OM} / \mathrm{OC}=2.9$ ) is the oligomer endpoint. These structures imply a smaller extent of oligomerization than suggested by the AMS elemental ratios. The AMS analysis technique may be underestimating the organic oxygen in the glyoxal/ $\left(\mathrm{NH}_{4}\right)_{2} \mathrm{SO}_{4}(\mathrm{aq})$ system but is within the reported measurement uncertainty of about $31 \%$ (Table S2, http://www.atmos-chem-phys.net/10/4111/2010/ acp-10-4111-2010-supplement.pdf).

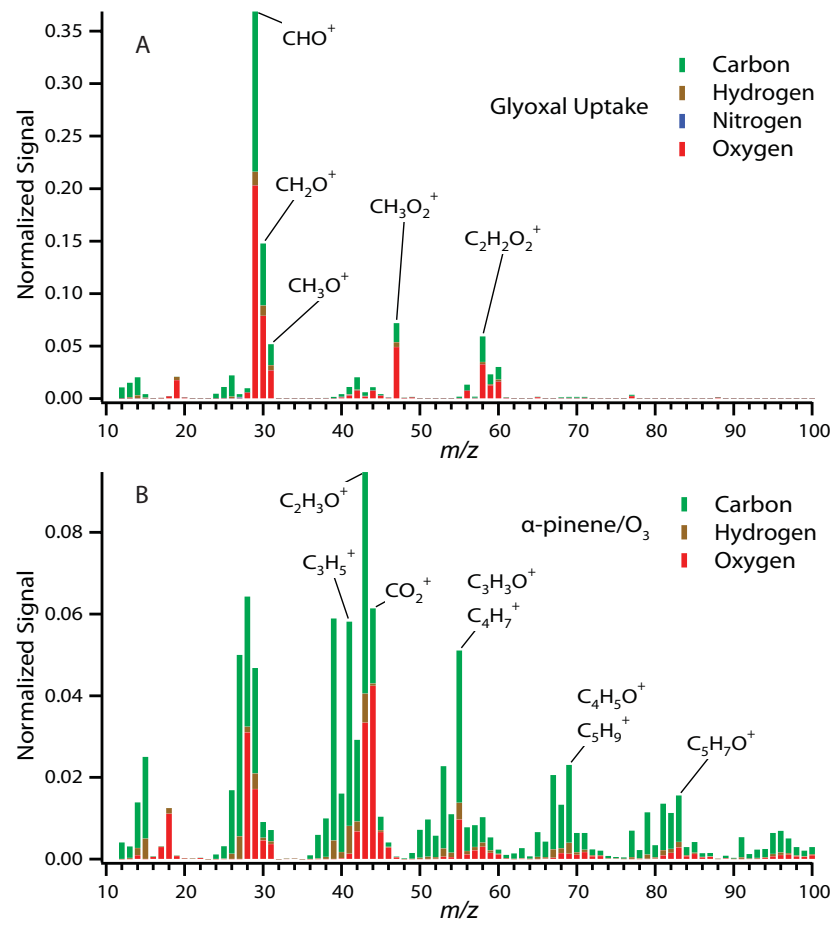

Fig. 2. High-resolution mass spectra of glyoxal (A) and $\alpha$-pinene (B) SOA with elemental contributions to each mass-to-charge ratio shown. Spectra are taken at the peak of SOA growth.

Figure 2a shows the contribution of each $\mathrm{m} / \mathrm{z}$ to the elemental composition of the organic mass at the peak of organic growth. About $56 \%$ of the signal comes from $\mathrm{CHO}^{+}, \mathrm{CH}_{2} \mathrm{O}^{+}$, and $\mathrm{CH}_{3} \mathrm{O}^{+}$fragments at $\mathrm{m} / \mathrm{z}, 29-31$, with smaller contributions from $\mathrm{CH}_{3} \mathrm{O}_{2}{ }^{+}, \mathrm{C}_{2} \mathrm{H}_{2} \mathrm{O}_{2}{ }^{+}, \mathrm{C}_{2} \mathrm{H}_{3} \mathrm{O}_{2}{ }^{+}$, and $\mathrm{C}_{2} \mathrm{H}_{4} \mathrm{O}_{2}{ }^{+}$. Together, these ions represent the bulk of the oxygen signal in the AMS spectra. As identified by Galloway et al. (2009), other distinct fragments that appear in the spectrum, $\mathrm{C}_{4} \mathrm{H}_{7} \mathrm{O}_{5}{ }^{+}, \mathrm{C}_{5} \mathrm{H}_{5} \mathrm{O}_{5}{ }^{+}$, and $\mathrm{C}_{6} \mathrm{H}_{7} \mathrm{O}_{6}{ }^{+}$, suggest the existence of oligomers of at least $n=3$. About $1 \%$ of the total AMS signal can be attributed to nitrogen-containing organic fragments resulting from the reaction of glyoxal with ammonium, producing imidazoles (Galloway et al., 2009). High-resolution spectra of these fragments are provided in the Supplemental Material (http://www.atmos-chem-phys. net/10/4111/2010/acp-10-4111-2010-supplement.pdf). Signals from the fragmentation of these compounds result in a measured N/C ratio for this system of about 0.01 . This is possibly an underestimate of the organic nitrogen signal as imidazoles may fragment into $\mathrm{NH}_{\mathrm{x}}{ }^{+}$ions. These ions are part of the "NH family" of ions and were not included as part of the organic signal since they are the primary fragments of ammonium in the ammonium sulfate seed.

After organic growth by glyoxal uptake had ceased in experiments 1 and 2, the chamber was diluted with clean air to investigate the reversibility of glyoxal uptake. As shown in Fig. 1, aerosol O/C decreases slowly after dilution, H/C stays 


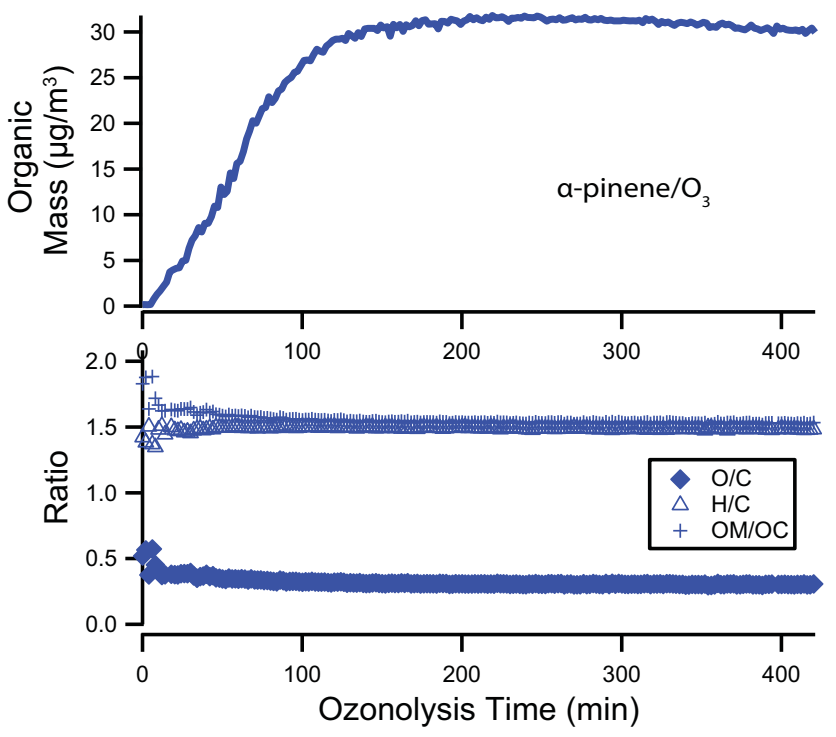

Fig. 3. AMS organic mass (not corrected for collection efficiency) $\mathrm{O} / \mathrm{C}, \mathrm{H} / \mathrm{C}$ and $\mathrm{OM} / \mathrm{OC}$ ratios for a typical $\alpha$-pinene ozonolysis experiment (Experiment 4).

approximately constant, and N/C increases gradually. The AMS organic signal and glyoxal markers decrease relative to sulfate during dilution, showing that glyoxal can repartition to the gas phase and that uptake is reversible (Galloway et al., 2009). Also, markers for N-containing compounds presumably formed from the reaction of glyoxal and ammonium, such as $1 \mathrm{H}$-imidazole-2-carboxaldehyde $\left(\mathrm{C}_{4} \mathrm{H}_{4} \mathrm{~N}_{2} \mathrm{O}\right.$, $\mathrm{O} / \mathrm{C}=0.25, \mathrm{H} / \mathrm{C}=1, \mathrm{~N} / \mathrm{C}=0.5)$, increase relative to sulfate. These $\mathrm{N}$-containing compounds are formed as ammonia replaces $\mathrm{H}_{2} \mathrm{O}$ as part of the organic phase.

\section{$3.2 \alpha$-pinene ozonolysis SOA}

The elemental and $\mathrm{OM} / \mathrm{OC}$ ratios for the four $\alpha$-pinene $/ \mathrm{O}_{3}$ SOA experiments evaluated here are similar so only data from experiment 4 are discussed. Figure 3 shows the evolution of $\mathrm{OM} / \mathrm{OC}, \mathrm{H} / \mathrm{C}$ and $\mathrm{O} / \mathrm{C}$ ratios of the SOA for experiment 4. The earliest aerosol formed has an $\mathrm{O} / \mathrm{C}$ ratio of 0.50 , which decreases throughout the experiment to approximately 0.30, close to the $\mathrm{O} / \mathrm{C}$ ratio reported by Aiken et al. (2008) for this system. The $\mathrm{H} / \mathrm{C}$ ratio increases from about 1.3 to 1.5. These ratios are in good agreement with the high-resolution AMS measurements of Shilling et al. (2009). This behavior has been explained by increased partitioning of less oxidized semivolatile compounds as the mass of partitioning medium grows (Shilling et al., 2009; Chan et al., 2009b). There is no substantial difference in SOA elemental composition between humid and dry experiments and experiments with and without $\mathrm{H}_{2} \mathrm{O}_{2}$.

$\alpha$-Pinene ozonolysis has served as a canonical SOA system for which the particle-phase composition of $\alpha$-pinene SOA has been investigated in numerous studies (Yu et al.,
1999; Jang and Kamens, 1999; Glasius et al., 2000; Koch et al., 2000; Iinuma et al., 2004; Gao et al., 2004). Using a denuder/filter pack sampling system and derivatization with GC-MS detection, Yu et al. (1999) were able to identify $>90 \%$ of the aerosol composition by mass at the molecular level. Using the molar yields reported in Yu et al. (1999), we calculate the aerosol-phase elemental ratios for their $\alpha$ pinene $/ \mathrm{O}_{3}$ experiments as shown in Supplemental Table S4. The composition analysis yields an $\mathrm{O} / \mathrm{C}$ range of $0.34-0.36$ and an $\mathrm{H} / \mathrm{C}$ range of $1.56-1.58$, which are very close to the AMS measured values. Using the Nanoaerosol Mass Spectrometer, Tolocka et al. (2006) determined the aerosol products of $\alpha$-pinene/ $\mathrm{O}_{3}$ to have an $\mathrm{O} / \mathrm{C}$ ratio of 0.37 to 0.4 for nucleated particles 30 and $50 \mathrm{~nm}$ in diameter. Reinhardt et al. (2007) used filter sampling in conjunction with electrospray ionization mass spectrometry to determine $\mathrm{O} / \mathrm{C}$ ratios of 0.4 to 0.6. In contrast to Yu et al. (1999), using an iodometricspectrophotometric technique, Docherty et al. (2005) estimated that nearly half of the SOA mass formed in $\alpha$-pinene ozonolysis comprised organic peroxides. Suggested compounds, such as peroxy pinalic acid $(\mathrm{O} / \mathrm{C}=0.44)$ and peroxypinic acid $(\mathrm{O} / \mathrm{C}=0.56)$, generally have higher $\mathrm{O} / \mathrm{C}$ ratios than those measured by Yu et al. (1999) but still close to the range measured in this study. A comparison of the elemental analyses in this work and others is given in Table 3.

Important ions in the $\alpha$-pinene $/ \mathrm{O}_{3}$ system are noted in Fig. 2b, with the largest contribution to the total organic signal coming from $\mathrm{C}_{2} \mathrm{H}_{3} \mathrm{O}^{+}(\mathrm{m} / \mathrm{z} 43)$ and the largest contribution to oxygen coming from $\mathrm{CO}_{2}{ }^{+}(\mathrm{m} / \mathrm{z}$ 44) at the peak of organic loading. Other prominent peaks reported by Shilling et al. (2009) are also observed. Over the course of the experiments evaluated here, the contribution of $\mathrm{m} / \mathrm{z}, 44$ to the organic signal decreases from approximately $11 \%$ to $6-7 \%$ as the organic mass increases.

\subsection{Isoprene SOA}

\subsubsection{Low-NO}

Figure 4 tracks the organic growth, isoprene decay, and elemental ratios for experiment 10 , the longest duration experiment conducted under low- $\mathrm{NO}_{\mathrm{x}}$ conditions. The SOA mass peaks soon after the onset of irradiation but then decreases rapidly. Kroll et al. (2006) suggested that the rapid loss in organic mass could be attributed to photolysis of semivolatile or condensed-phase hydroperoxides, as the decay occurred only under irradiation and only in a low- $\mathrm{NO}_{\mathrm{x}}$ environment. This hypothesis was supported by Surratt et al. (2006) who found, using iodometric-spectrophotometric measurements, that the contribution of organic peroxides decreased from $59 \%$ of the total SOA mass to $26 \%$ over the $12 \mathrm{~h}$ duration.

For low- $\mathrm{NO}_{\mathrm{x}}$ isoprene $\mathrm{SOA}$, the $\mathrm{O} / \mathrm{C}$ ratio is approximately 0.60 at the onset of photooxidation, decreasing gradually to 0.50 in the longest duration experiment. The $\mathrm{H} / \mathrm{C}$ ratio starts at approximately 1.2 , increases to 1.6 , and then 
Table 3. $\mathrm{O} / \mathrm{C}$ ratios of various laboratory SOA systems.

\begin{tabular}{lrll}
\hline System & O/C Ratio & Method & Reference \\
\hline glyoxal uptake & 1.13 & HR-ToF-AMS & This Study \\
$\alpha$-pinene $+\mathrm{O}_{3}$ & $0.30-0.43$ & HR-ToF-AMS & This Study \\
& $0.29-0.45$ & HR-ToF-AMS & Shilling et al. (2009) \\
& 0.27 & HR-ToF-AMS & Aiken et al. (2008) \\
& $0.4-0.6$ & ESI-FTICR-MS & Reinhardt et al. (2007) \\
$\beta$-pinene $+\mathrm{O}_{3}$ & $0.37-0.4$ & NAMS & Tolocka et al. (2006) \\
$\Delta^{3}$-carene $+\mathrm{O}_{3}$ & 0.45 & NAMS & Heaton et al. (2007) \\
limonene $+\mathrm{O}_{3}$ & 0.43 & NAMS & Heaton et al. (2007) \\
& 0.45 & NAMS & Heaton et al. (2007) \\
sabinene $+\mathrm{O}_{3}$ & $0.43-0.50$ & ESI-MS (Orbitrap) & Walser et al. (2008) \\
$\alpha$-pinene $+\mathrm{NO}_{\mathrm{x}}$ & 0.37 & NAMS & Heaton et al. (2007) \\
isoprene $+\mathrm{OH}$ & 0.39 & HR-ToF-AMS & Aiken et al. (2008) \\
& 0.41 & HR-ToF-AMS & Aiken et al. (2008) \\
toluene $+\mathrm{OH}$ & $0.50-0.62$ & HR-ToF-AMS & This Study \\
& 0.43 & HR-ToF-AMS & Aiken et al. (2008) \\
$m$-xylene $+\mathrm{OH}$ & $0.50-0.74$ & HR-ToF-AMS & This Study \\
naphthalene $+\mathrm{OH}$ & $0.50-0.66$ & HR-ToF-AMS & This Study \\
& $0.30-0.74$ & HR-ToF-AMS & This Study
\end{tabular}

steadily decreases to 1.45 . Using offline filter analyses, several classes of compounds have been identified as constituents of SOA from the photooxidation of isoprene under low- $\mathrm{NO}_{\mathrm{x}}$ conditions with ammonium sulfate seed, including dihydroxydihydroperoxides $(\mathrm{O} / \mathrm{C}=1.2, \mathrm{H} / \mathrm{C}=2.4)$, epoxydiols $(\mathrm{O} / \mathrm{C}=0.6, \mathrm{H} / \mathrm{C}=2), \mathrm{C}_{5}$-alkene triols $(\mathrm{O} / \mathrm{C}=0.6, \mathrm{H} / \mathrm{C}=2)$, 2-methyltetrols $(\mathrm{O} / \mathrm{C}=0.8, \mathrm{H} / \mathrm{C}=2.4)$, and hydroxyl sulfate esters $(\mathrm{O} / \mathrm{C}=1.4, \mathrm{H} / \mathrm{C}=2.4, \mathrm{~S} / \mathrm{C}=0.2)$ (Claeys et al., 2004; Wang et al., 2005; Surratt et al., 2006, 2007; GómezGonzález et al., 2008; Surratt et al., 2010). Oligomers of 2methyltetrols and hydroxy sulfate esters have also been measured (Surratt et al., 2006, 2008). An O/C value of 0.6 is consistent with SOA consisting of epoxydiols and $\mathrm{C}_{5}$-alkene triols. However, numerous studies have reported peroxides and 2-methyltetrols as major constituents as well, both having higher degrees of oxygenation. Tetrol dimers and sulfate esters will also have $\mathrm{O} / \mathrm{C}$ ratios higher than 0.6. Therefore, the expected particle-phase composition of isoprene$\mathrm{OH}$ SOA has higher $\mathrm{O} / \mathrm{C}$ and $\mathrm{H} / \mathrm{C}$ ratios than those measured by the AMS, reasons for which will be discussed in Sect. 4.2. However, the slow decay of the O/C ratio over time could reflect the photolysis of hydoxyhydroperoxide compounds or reaction with $\mathrm{OH}$ radicals (Lee et al., 2000). Photolysis would split the peroxy bond, releasing an $\mathrm{OH}$ radical. The subsequent alkoxy radical would then react with $\mathrm{O}_{2}$ to form an aldehyde and $\mathrm{HO}_{2}$. Reaction with $\mathrm{OH}$ would abstract a hydrogen leaving an alkoxy peroxy radical which could then further decompose. Overall these processes have the potential to deplete both oxygen and hydrogen relative to carbon, reducing their elemental ratios.

The time dependence of the $\mathrm{H} / \mathrm{C}$ ratio is consistent with the effects of two different processes. $\mathrm{H} / \mathrm{C}$ rises quickly to a peak at about $200 \mathrm{~min}$ into the experiment, coinciding with the peak of SOA growth. The increasing amount of OA provides

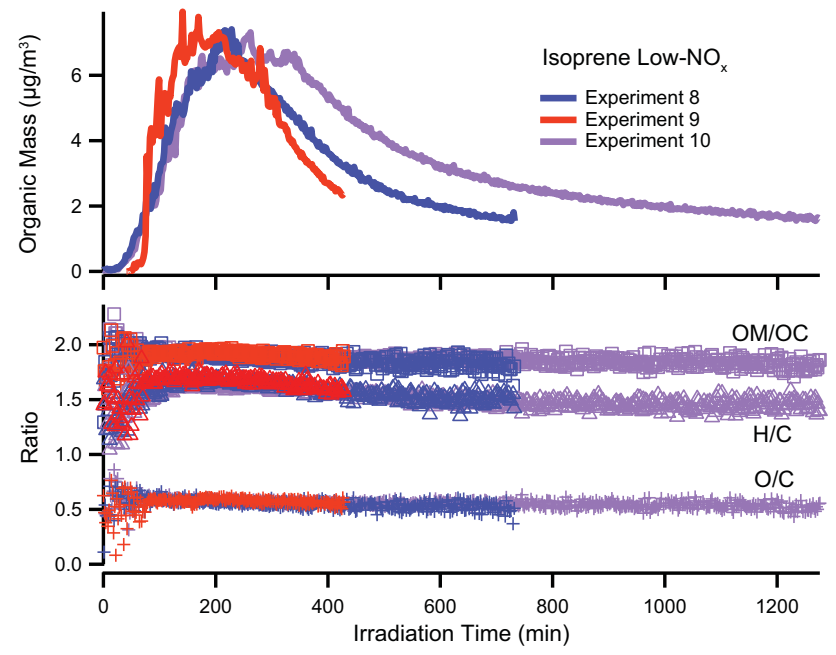

Fig. 4. Bottom Panel: AMS organic mass loading (not corrected for collection efficiency) for isoprene low- $\mathrm{NO}_{\mathrm{x}}$ experiments. Bottom Panel: O/C, H/C and OM/OC ratios of isoprene SOA formed under low- $\mathrm{NO}_{\mathrm{x}}$ conditions. Experiment 8 is in blue, 9 in red, and 10 in purple.

a medium for continued partitioning of semivolatile species with a higher $\mathrm{H} / \mathrm{C}$ ratio into the particle phase. This effect is also seen in the $\mathrm{H} / \mathrm{C}$ ratio of $\alpha$-pinene ozonolysis SOA. However, as noted earlier, with continued irradiation, peroxide compounds could photolyze or react with $\mathrm{OH}$, causing the $\mathrm{H} / \mathrm{C}$ ratio to decrease. The decrease in $\mathrm{H} / \mathrm{C}$ and $\mathrm{O} / \mathrm{C}$ ratios could also be explained by oligomerization, as $\mathrm{H}_{2} \mathrm{O}$ is lost through condensation reactions.

The spectrum of low- $\mathrm{NO}_{\mathrm{x}}$ isoprene SOA changes throughout irradiation time reflecting the continued processing of the SOA, consistent with the observed rapid decay in organic aerosol mass. At the peak of aerosol growth about $85 \%$ of the organic signal occurs for $m / z \leq 45$. The strongest signals occur at $\mathrm{COH}^{+}$and $\mathrm{C}_{2} \mathrm{H}_{3} \mathrm{O}^{+}$, representing approximately $30 \%$ of the organic signal as displayed in Fig. 5a, with most of the oxygen content coming from $\mathrm{COH}^{+}$. The spectrum changes considerably after $20 \mathrm{~h}$ of irradiation with the contribution of the organic signal decreasing to $75 \%$ for $m / z \leq 45$ and contributions of $m / z>100$ increasing. Mass fragment $\mathrm{CO}_{2}{ }^{+}$also becomes the dominant contributor of oxygen to the SOA. Unit-mass resolution AMS data from Surratt et al. (2006) indicate an increasing signal at $m / z>200$ over the course of the experiment, suggesting oligomerization even as organic mass is decreasing. The authors of this previous study also proposed $m / z 91$ as an AMS tracer ion for peroxides, as the ion reaches its peak signal earlier than that of organics and decreases faster than wall loss. The high-resolution study here confirms the existence of their ion assignment of $\mathrm{C}_{3} \mathrm{H}_{7} \mathrm{O}_{3}{ }^{+}$, though it also occurs with $\mathrm{C}_{7} \mathrm{H}_{7}{ }^{+}$(see Supplemental Material). 

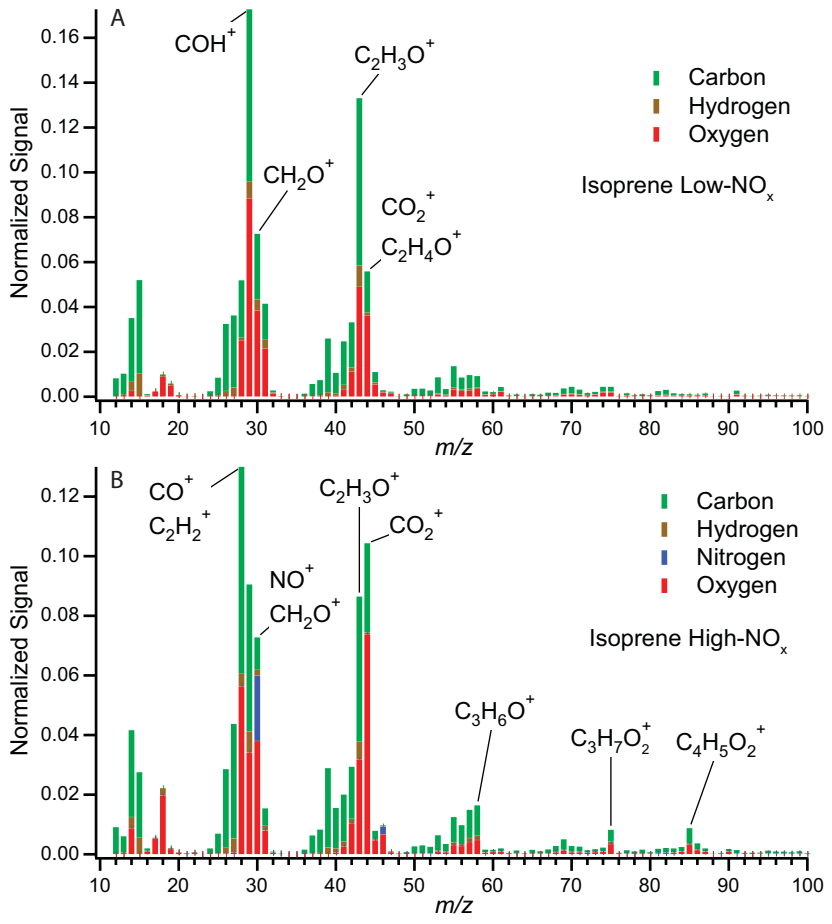

Fig. 5. High-resolution mass spectra of isoprene SOA formed under low- $\mathrm{NO}_{\mathrm{x}}(\mathbf{A})$ and high- $\mathrm{NO}_{\mathrm{x}}(\mathbf{B})$ conditions with elemental contributions to each mass-to-charge ratio shown. Spectra are taken at the peak of SOA growth.

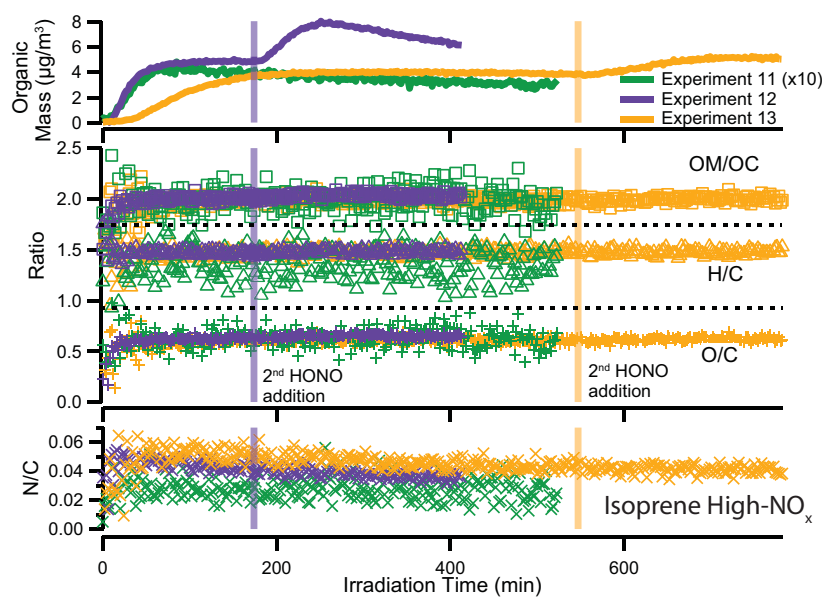

Fig. 6. AMS organic mass (not corrected for collection efficiency), elemental ratios, and $\mathrm{OM} / \mathrm{OC}$ for isoprene high- $\mathrm{NO}_{\mathrm{x}}$ experiments. Experiment 11 is in green, 12 in purple, and 13 in orange. Dotted lines are provided to visually separate different ratios.

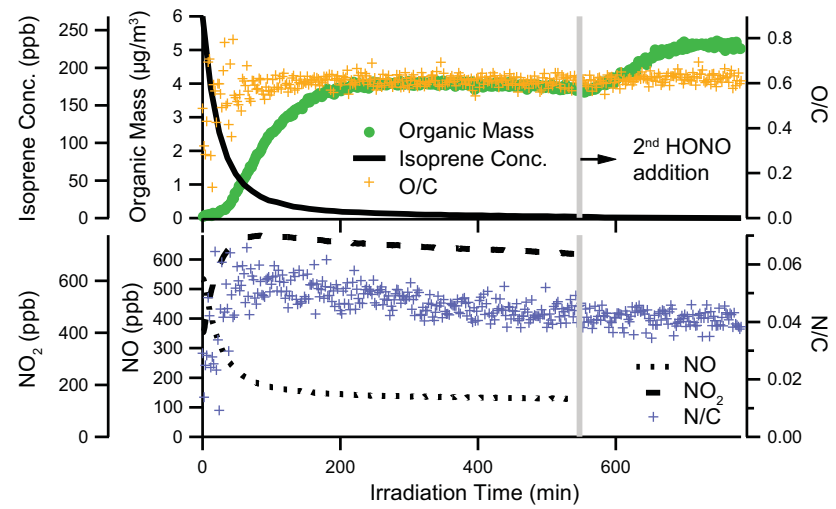

Fig. 7. Top panel: Time dependence of AMS organic mass (not corrected for collection efficiency), $\mathrm{O} / \mathrm{C}$ ratio, and isoprene concentration for Experiment 12. Bottom panel: Time dependence of $\mathrm{NO}, \mathrm{NO}_{2}$, and $\mathrm{N} / \mathrm{C}$ ratio for Experiment 12. A second addition of $\mathrm{HONO}$ at about $550 \mathrm{~min}$ after the start of the experiment is marked.

\subsubsection{High-NO ${ }_{x}$}

Under high- $\mathrm{NO}_{\mathrm{x}}$ conditions, isoprene $\mathrm{SOA}$ is characterized by $\mathrm{O} / \mathrm{C}$ atomic ratios generally higher than those of low- $\mathrm{NO}_{\mathrm{x}}$ experiments. As illustrated in Fig. 6, H/C, O/C and OM/OC ratios quickly plateau to $1.46,0.62$, and 2.00 , respectively, and do not change over the course of the experiments. The N/C ratio, however, peaks early at approximately 0.05 and decreases thereafter. Figure 7 compares the organic growth and isoprene decay to the $\mathrm{O} / \mathrm{C}$ ratio, and the gas-phase $\mathrm{NO}$ and $\mathrm{NO}_{2}$ concentrations to the $\mathrm{N} / \mathrm{C}$ ratio for experiment 12 , conducted under high- $\mathrm{NO}_{\mathrm{x}}$ conditions. In contrast to low$\mathrm{NO}_{\mathrm{x}}$ experiments, as the isoprene concentration drops, organic mass grows to a plateau about $4 \mathrm{~h}$ after irradiation begins. After organic growth levels out, additional HONO is added to convert any existing gas-phase intermediates such as methacrolein and peroxymethacroyl nitrate (MPAN) (Surratt et al., 2010); additional SOA is formed but no change in elemental composition is observed.

Previous work has established that the main constituents of SOA derived from isoprene photooxidation under high$\mathrm{NO}_{\mathrm{x}}$ conditions are 2-methylglyceric acid $(\mathrm{O} / \mathrm{C}=1, \mathrm{H} / \mathrm{C}=2)$, the hydroxynitrate of 2-methylglyceric acid $(\mathrm{O} / \mathrm{C}=1.75$, $\mathrm{H} / \mathrm{C}=1.75, \mathrm{~N} / \mathrm{C}=0.25$ ), and their corresponding oligoesters (Surratt et al., 2006, 2010; Szmigielski et al., 2007) from detailed offline chemical analyses of filter samples. These compounds have been estimated to represent approximately $20 \%$ of the SOA mass (Surratt et al., 2006). Thus the AMS elemental ratios are below those that would be expected from offline filter analysis. Even if one considers the linear oligomerization of 2-methylglyceric acid by esterification, which will reduce the $\mathrm{O} / \mathrm{C}$ and $\mathrm{H} / \mathrm{C}$ ratios by removing $\mathrm{H}_{2} \mathrm{O}$, the $\mathrm{O} / \mathrm{C}$ ratio will not fall below 0.75 and the $\mathrm{H} / \mathrm{C}$ ratio will not fall below 1.5 . 


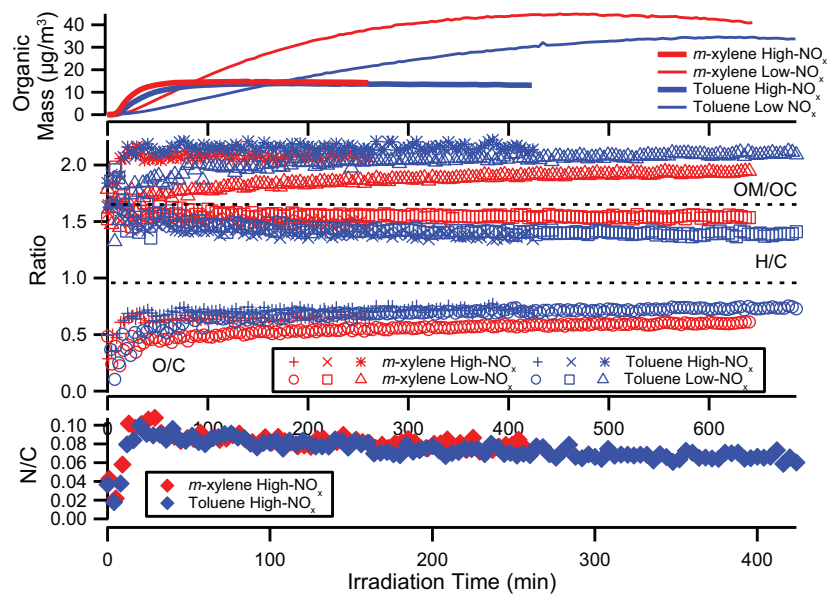

Fig. 8. AMS organic mass (not corrected for collection efficiency), elemental ratios, and OM/OC for single-ring aromatic experiments. Dotted lines are provided to visually separate different ratios.

SOA derived from isoprene photooxidation under high$\mathrm{NO}_{\mathrm{x}}$ conditions also has non-negligible nitrogen content. The nitrogen is likely organic in nature as the gas-phase concentration of $\mathrm{NO}_{2}$ remains high throughout the experiment (Fig. 7), and recent work has shown that a major route to form isoprene-SOA under high- $\mathrm{NO}_{\mathrm{x}}$ conditions occurs through the reaction of the methacrolein peroxy radical with $\mathrm{NO}_{2}$ to form MPAN (Surratt et al., 2010). Aerosol-phase compounds containing nitrogen are presumably the hydroxynitrate of 2-methylglyceric acid or nitroxypolyols, which fragment in the AMS forming $\mathrm{NO}^{+}$and $\mathrm{NO}_{2}{ }^{+}$ions (Fig. 5b). While the addition of extra HONO produces more SOA, it does not alter the elemental ratios, and continued irradiation led to no measurable aerosol processing (Fig. 7). If the aerosol-phase nitrogen resulted from the uptake of $\mathrm{HNO}_{3}$, one would expect a jump in the N/C ratio with the second addition of HONO, just as in the beginning of the experiment. The N/C ratio decreases throughout the experiment, which could be the result of hydrolysis of the aerosol-phase organonitrates to form volatile nitric acid (Sato, 2008), or photolysis to form an alkoxy radical and $\mathrm{NO}_{2}$ (Renbaum and Smith, 2009; Roberts and Fajer, 1989). The steady oxygen and hydrogen content of the isoprene high- $\mathrm{NO}_{\mathrm{x}} \mathrm{SOA}$ is supported by the relatively constant HR spectra. In contrast to the low- $\mathrm{NO}_{\mathrm{x}}$ isoprene $\mathrm{SOA}$ spectrum (Fig. 5a), much of the oxygen in the high- $\mathrm{NO}_{\mathrm{x}}$ AMS spectrum comes from $\mathrm{CO}_{2}{ }^{+}$.

\subsection{Single-ring aromatic SOA}

Figure 8 shows the $\mathrm{O} / \mathrm{C}, \mathrm{H} / \mathrm{C}, \mathrm{N} / \mathrm{C}$ and $\mathrm{OM} / \mathrm{OC}$ ratios for single-ringed aromatic SOA experiments (i.e., $m$-xylene and toluene). Maximum $\mathrm{O} / \mathrm{C}$ ratios ranged from 0.60 to 0.73 . Toluene SOA under high- $\mathrm{NO}_{\mathrm{x}}$ conditions achieves an $\mathrm{O} / \mathrm{C}$ of about 0.7. Low- $\mathrm{NO}_{\mathrm{x}}$ experiments begin with low $\mathrm{O} / \mathrm{C}$ values that increase with continued irradiation. The $\mathrm{O} / \mathrm{C}$ of high- $\mathrm{NO}_{\mathrm{x}} \mathrm{SOA}$ increases with continued irradiation as well, albeit more slowly. The $\mathrm{N} / \mathrm{C}$ ratio of high $-\mathrm{NO}_{\mathrm{x}} \mathrm{SOA}$ peaks at 0.10 shortly after irradiation begins, but decreases gradually throughout the experiment.

While numerous studies have investigated the chemical composition of SOA from toluene photooxidation, as well as other aliphatic aromatic compounds, usually in the presence of $\mathrm{NO}_{\mathrm{x}}$, quantification of particle-phase organic species has proved difficult (Hamilton et al., 2005; Sato et al., 2007). Kalberer et al. (2004) found that a large fraction of the SOA formed from trimethylbenzene was oligomeric; proposed polymer structures lead to an $\mathrm{O} / \mathrm{C}$ ratio of 1.0 , and peaks from LDI-MS spectra have $\mathrm{O} / \mathrm{C}$ ratios ranging from 0.7 to 1.6. For the same system, Fisseha et al. (2004) found that organic acids constitute 20 to $45 \%$ of the organic mass. If one considers the small organic acids quantified by Fisseha et al. (2004), O/C ratios would range from 1 to 2, substantially higher than those measured in the experiments surveyed here. Furthermore, aromatic photooxidation yields considerable amounts of glyoxal, methylglyoxal, and other multifunctional carbonyls that, if incoporated into the SOA, would produce high O/C ratios (Bloss et al., 2005; Hamilton et al., 2005, 2003; Kalberer et al., 2004). However, with the number of less oxygenated compounds measured, including aromatic ring-retaining compounds, unsaturated acids, ketones and aldehydes (Sato et al., 2007; Hamilton et al., 2005; Jang and Kamens, 2001), the measured O/C could accurately represent the oxygen content of the SOA formed.

AMS data indicate that $m$-xylene-derived SOA has a lower $\mathrm{O} / \mathrm{C}$ ratio than that of toluene SOA. This is likely due to the presence of the second methyl group in $m$-xylene. For both $\mathrm{NO}_{\mathrm{x}}$ conditions and hydrocarbons, the $\mathrm{O} / \mathrm{C}$ ratio continues to increase over the course of oxidation, indicating continued oxidation of the aerosol even after the organic loading has peaked. This prolonged processing, perhaps as a result of $\mathrm{OH}$ oxidation of unsaturated compounds in the particle phase or of vapor-phase semivolatile species, leads to a greater contribution of $\mathrm{CO}_{2}{ }^{+}$to the organic signal in each experiment. The $\mathrm{SOA}$ from both high- $\mathrm{NO}_{\mathrm{x}}$ experiments had similar $\mathrm{N} / \mathrm{C}$ ratios. Under high- $\mathrm{NO}_{\mathrm{x}}$ conditions, organic nitrogen is expected as evidenced by the presence of nitroaromatics (Hamilton et al., 2005; Sato et al., 2007; Jang and Kamens, 2001). Compounds, like nitrocresols and nitrotoluenes, form from the reaction of the $\mathrm{OH}$-aromatic adduct with $\mathrm{NO}_{2}$, which under high- $\mathrm{NO}_{\mathrm{x}}$ conditions has the same concentration profile as in Fig. 8. N/C decreasing could reflect the continued photoooxidation of these compounds in the gas or particle phases.

At the peak of SOA growth, toluene SOA exhibits similar spectra regardless of $\mathrm{NO}_{\mathrm{x}}$ level (Fig. 9), except for the existence of the $\mathrm{NO}^{+}$and $\mathrm{NO}_{2}{ }^{+}$ions in high- $\mathrm{NO}_{\mathrm{x}}$ spectra. Mass fragment $\mathrm{CO}_{2}{ }^{+}$contributes nearly the same amount to the organic signal as $\mathrm{C}_{2} \mathrm{H}_{3} \mathrm{O}^{+}$in toluene experiments. Conversely, $\mathrm{C}_{2} \mathrm{H}_{3} \mathrm{O}^{+}$is the dominant ion in $m$-xylene SOA spectra, representing $19 \%$ of the organic signal in low- $\mathrm{NO}_{\mathrm{x}}$ conditions 

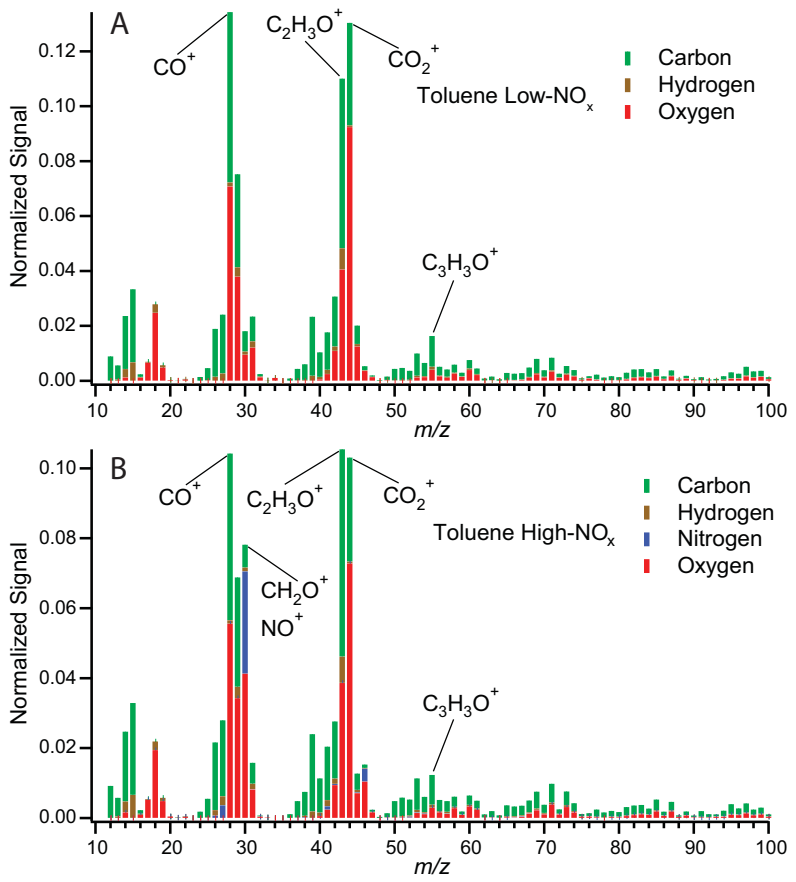

Fig. 9. High-resolution mass spectra of toluene SOA formed under low- $\mathrm{NO}_{\mathrm{x}}$ (A) and high- $\mathrm{NO}_{\mathrm{x}}$ (B) conditions with elemental contributions to each mass-to-charge ratio shown. Spectra are taken at the peak of SOA growth.

and $15 \%$ in high- $\mathrm{NO}_{\mathrm{x}}$ conditions (Fig. 9). In both systems, the fraction of $\mathrm{CO}_{2}{ }^{+}$increases with continued irradiation with $\mathrm{f}_{44}$ ranging from $10-13 \%$ for toluene SOA and $8-10 \%$ for $m$-xylene SOA. These ranges of $\mathrm{f}_{44}$ values were also observed by Sato et al. (2010).

\subsection{Naphthalene SOA}

Figures 11 and 12 show the elemental ratios for SOA derived from naphthalene photooxidation at high- and low- $\mathrm{NO}_{\mathrm{x}}$ conditions, respectively. $\mathrm{O} / \mathrm{C}$ ratios under low- $\mathrm{NO}_{\mathrm{x}}$ conditions decrease sharply to 0.30 early in the experiments, but then increase to above 0.70 in the longest experiment. $\mathrm{H} / \mathrm{C}$ ratios decrease from approximately 1.0 to 0.9 . $\mathrm{O} / \mathrm{C}$ and $\mathrm{H} / \mathrm{C}$ ratios for high- $\mathrm{NO}_{\mathrm{x}}$ experiments exhibit similar characteristics; $\mathrm{O} / \mathrm{C}$ ratios start from about 0.35 at the beginning of irradiation and then increase steadily to 0.60 in the longest experiment, but no initial decrease occurred. $\mathrm{H} / \mathrm{C}$ ratios decrease from 1.0 to approximately 0.8 . N/C profiles under high- $\mathrm{NO}_{\mathrm{x}}$ conditions resemble those of isoprene and aromatic high- $\mathrm{NO}_{\mathrm{x}}$ systems, starting high at 0.10 and decreasing with continued irradiation. Figure 14 show the spectra for SOA derived under both $\mathrm{NO}_{\mathrm{x}}$ levels.

The elemental values measured by the AMS are close to those determined in a comprehensive study of naphthalene photooxidation by Kautzman et al. (2010), who characterized, from detailed offline chemical analyses of filter sam-
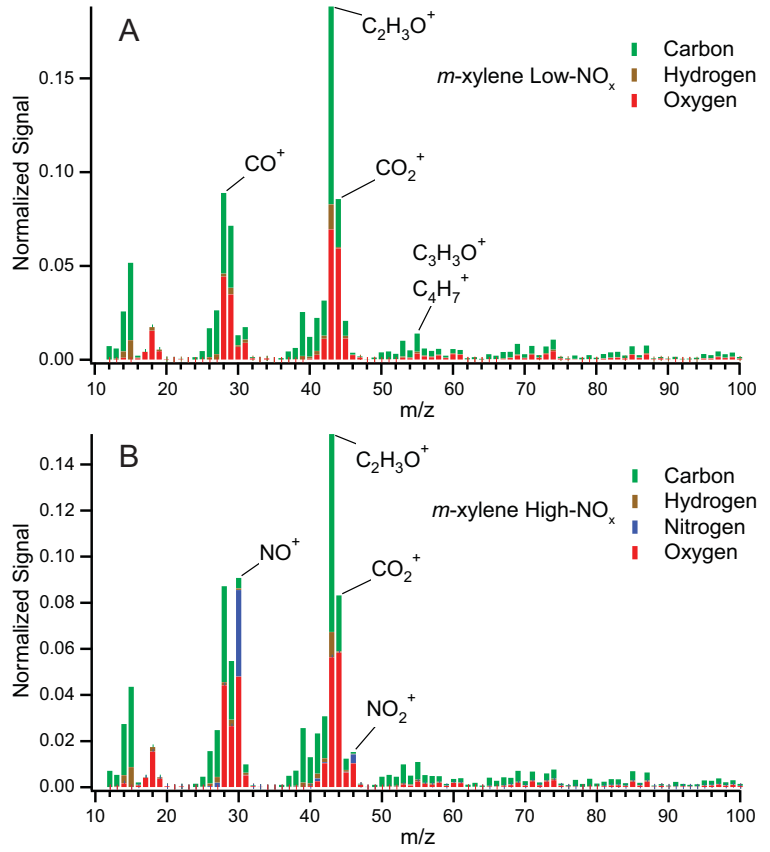

Fig. 10. High-resolution mass spectra of $m$-xylene SOA formed under low- $\mathrm{NO}_{\mathrm{x}}(\mathbf{A})$ and high- $\mathrm{NO}_{\mathrm{x}}(\mathbf{B})$ conditions with elemental contributions to each mass-to-charge ratio shown. Spectra were taken at the peak of SOA growth.

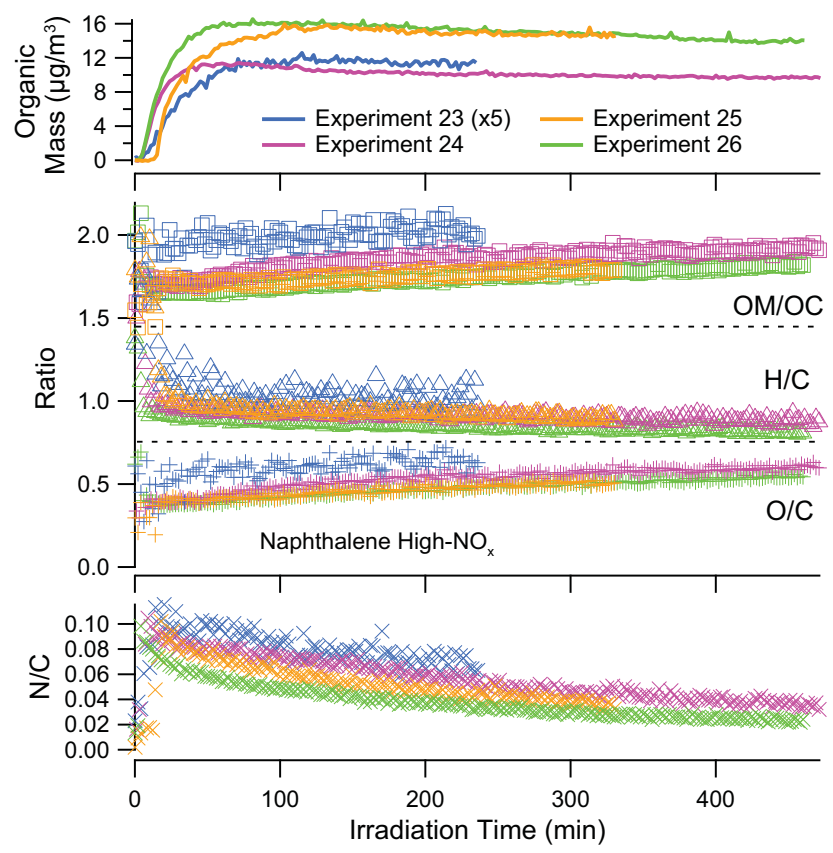

Fig. 11. Organic mass (not corrected for collection efficiency), elemental ratios, and $\mathrm{OM} / \mathrm{OC}$ for naphthalene high- $\mathrm{NO}_{\mathrm{x}}$ experiments. Experiment 23 is in blue, 24 in pink, 25 in orange and 26 in green. Dotted lines are provided to visually separate different ratios. 


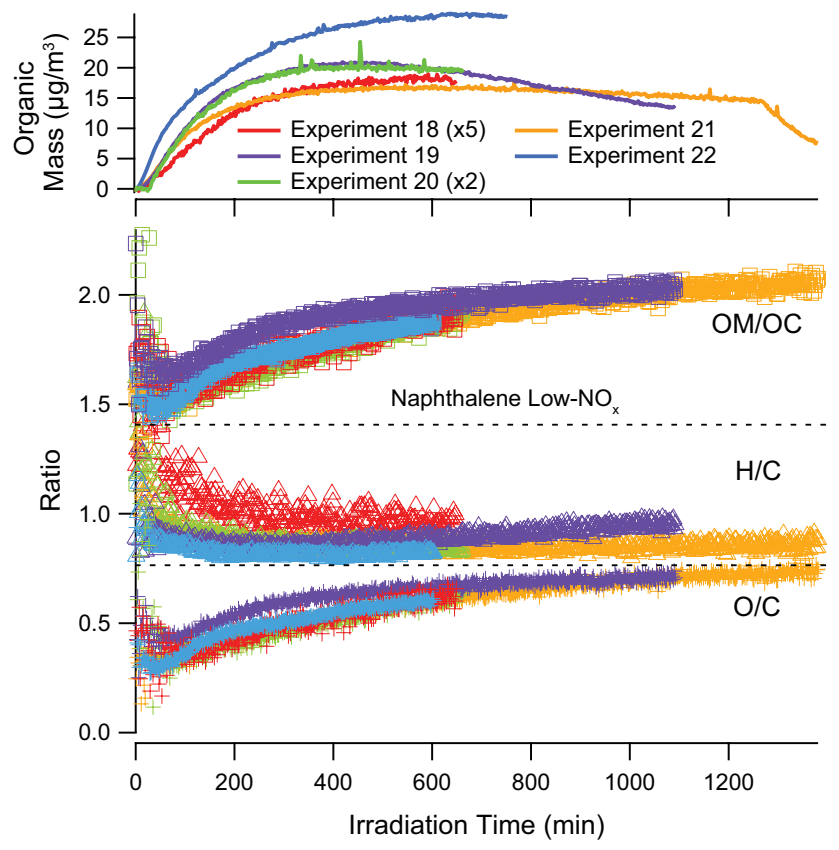

Fig. 12. AMS organic mass (not corrected for collection efficiency), elemental ratios, and $\mathrm{OM} / \mathrm{OC}$ for naphthalene low- $\mathrm{NO}_{\mathrm{x}}$ experiments. Experiment 18 is in red, 19 in purple, 20 in green, 21 in orange, and 22 in blue. Dotted lines are provided to visually separate different ratios.

ples, $68 \%$ and $53 \%$ of the SOA mass under low- $\mathrm{NO}_{\mathrm{x}}$ and high- $\mathrm{NO}_{\mathrm{x}}$ conditions, respectively. Acidic species and peroxides represented a major portion of the SOA in both $\mathrm{NO}_{\mathrm{x}}$ regimes, and nitrogen-containing constituents were $3 \%$ of the total SOA mass formed under high- $\mathrm{NO}_{\mathrm{x}}$ conditions. The $\mathrm{O} / \mathrm{C}$ and $\mathrm{H} / \mathrm{C}$ ratios calculated in that study were 0.50 and 0.82 under low- $\mathrm{NO}_{\mathrm{x}}$ conditions and 0.48 and 0.83 under high- $\mathrm{NO}_{\mathrm{x}}$ conditions. The N/C ratios measured by the AMS varied from 0.02 to 0.10 for SOA formed at high- $\mathrm{NO}_{\mathrm{x}}$ conditions, in good agreement with Kautzman et al. (2010), as they estimate a lower bound estimate of N/C to be 0.04 from filter techniques.

Under low- $\mathrm{NO}_{\mathrm{x}}$ conditions, $\mathrm{O} / \mathrm{C}$ values descend slightly within the first hour of irradiation, which is likely a result of less oxygenated species partitioning into the growing organic phase. This phenomenon is not observed in the high- $\mathrm{NO}_{\mathrm{x}}$ case, presumably because the high rates of oxidation and aerosol growth obscure this effect. As in the single-ringed aromatic experiments, the $\mathrm{O} / \mathrm{C}$ ratio of naphthalene-derived SOA increases well after the organic mass has reached a maximum in both $\mathrm{NO}_{\mathrm{x}}$ regimes (Fig. 13). This behavior is consistent with continued $\mathrm{OH}$ oxidation of semivolatile species, since most of the gas- and aerosol-phase species still retain aromaticity and unsaturation that are susceptible to oxidation by $\mathrm{OH}$. Under high- $\mathrm{NO}_{\mathrm{x}}$ conditions, the rapid decline of N/C could explained by photolysis of nitrogen containing compounds (Atkinson et al., 1989; Kautzman et al., 2010).

\section{Discussion}

\subsection{Overall trends in $\mathrm{O} / \mathrm{C}$ ratios from laboratory chamber-generated SOA}

Of the VOCs studied here, glyoxal is unique because no oxidant initiates SOA formation. Based solely on its vapor pressure, glyoxal, the smallest dicarbonyl, would not be expected to produce SOA . Due to its ability to hydrate and polymerize, however, glyoxal has a large effective Henry's law constant (Loeffler et al., 2006; Ip et al., 2009). These properties, along with its small carbon number, lead to the largest O/C of any system studied here and a measured $\mathrm{O} / \mathrm{C}$ ratio greater than 1.

Although $\alpha$-pinene along with naphthalene, has the highest carbon number, it produced the least oxygenated SOA. This is because, with 10 carbons, $\alpha$-pinene has only one double bond that is the only active site for ozone reaction. The lack of subsequent ozonolysis reactions limit oxygenation to first-generation products, primarily consisting of oxocarboxylic acids, dicarboxylic acids, and hydroxyl pinonic acid (Yu et al., 1999). This is supported by the chamber AMS data reported by $\mathrm{Ng}$ et al. (2006), which shows that the SOA chemistry is virtually constant over time. AMS elemental analysis confirms this as $\mathrm{O} / \mathrm{C}$ and $\mathrm{H} / \mathrm{C}$ ratios remain unchanged after semivolatile partitioning has reached equilibrium.

Like single-ringed aromatic SOA, the O/C ratios of naphthalene SOA increase with irradiation time, surpassing 0.7 for the longest low- $\mathrm{NO}_{\mathrm{x}}$ experiments. The aromaticity of naphthalene, toluene, and $m$-xylene allow for multiple oxidation steps through ring opening and bicyclic peroxy radical routes (Kautzman et al., 2010; Bloss et al., 2005; Alvarez et al., 2007). The different rates of $\mathrm{O} / \mathrm{C}$ ratio growth between high- and low- $\mathrm{NO}_{\mathrm{x}}$ conditions can be explained by the source of $\mathrm{OH}$ radicals. Under high- $\mathrm{NO}_{\mathrm{x}}$ conditions, the rapid photolysis of $\mathrm{HONO}$ yields high concentrations of $\mathrm{OH}$ radicals $\left(\sim 3 \times 10^{7}\right.$ molecules $\left.\mathrm{cm}^{-3}\right)$ at the onset of irradiation, which promptly generates SOA. SOA growth slows once HONO is consumed and $\mathrm{OH}$ radicals are produced through $\mathrm{NO}_{\mathrm{x}} / \mathrm{HO}_{\mathrm{x}}$ cycling. Thus, under high- $\mathrm{NO}_{\mathrm{x}}$ conditions, $\mathrm{O} / \mathrm{C}$ ratios for naphthalene and single-ringed aromatic-SOA start high, and then increase slowly afterward, as depicted in Fig. 13. Under low- $\mathrm{NO}_{\mathrm{x}}$ conditions, ppm levels of $\mathrm{H}_{2} \mathrm{O}_{2}$ are needed to reach an adequate $\mathrm{OH}$ concentration and $\mathrm{OH}$ levels are lower $\left(\sim 3 \times 10^{6}\right.$ molecules $\left.\mathrm{cm}^{-3}\right)$ but more constant throughout the experiment. O/C ratios of the earliest formed low$\mathrm{NO}_{\mathrm{x}}$ SOA are lower than in the high- $\mathrm{NO}_{\mathrm{x}}$ case, but grow steadily throughout.

Of the 5 carbons of isoprene, four are subject to $\mathrm{OH}$ attack, leading to higher $\mathrm{O} / \mathrm{C}$ ratios than SOA from $\alpha$-pinene ozonolysis. Isoprene photooxidation yields very different SOA products depending on the $\mathrm{NO}_{\mathrm{x}}$ level. Under low$\mathrm{NO}_{\mathrm{x}}$ conditions, isoprene photooxidation products consist predominantly of polyols and peroxides (Surratt et al., 2006, 

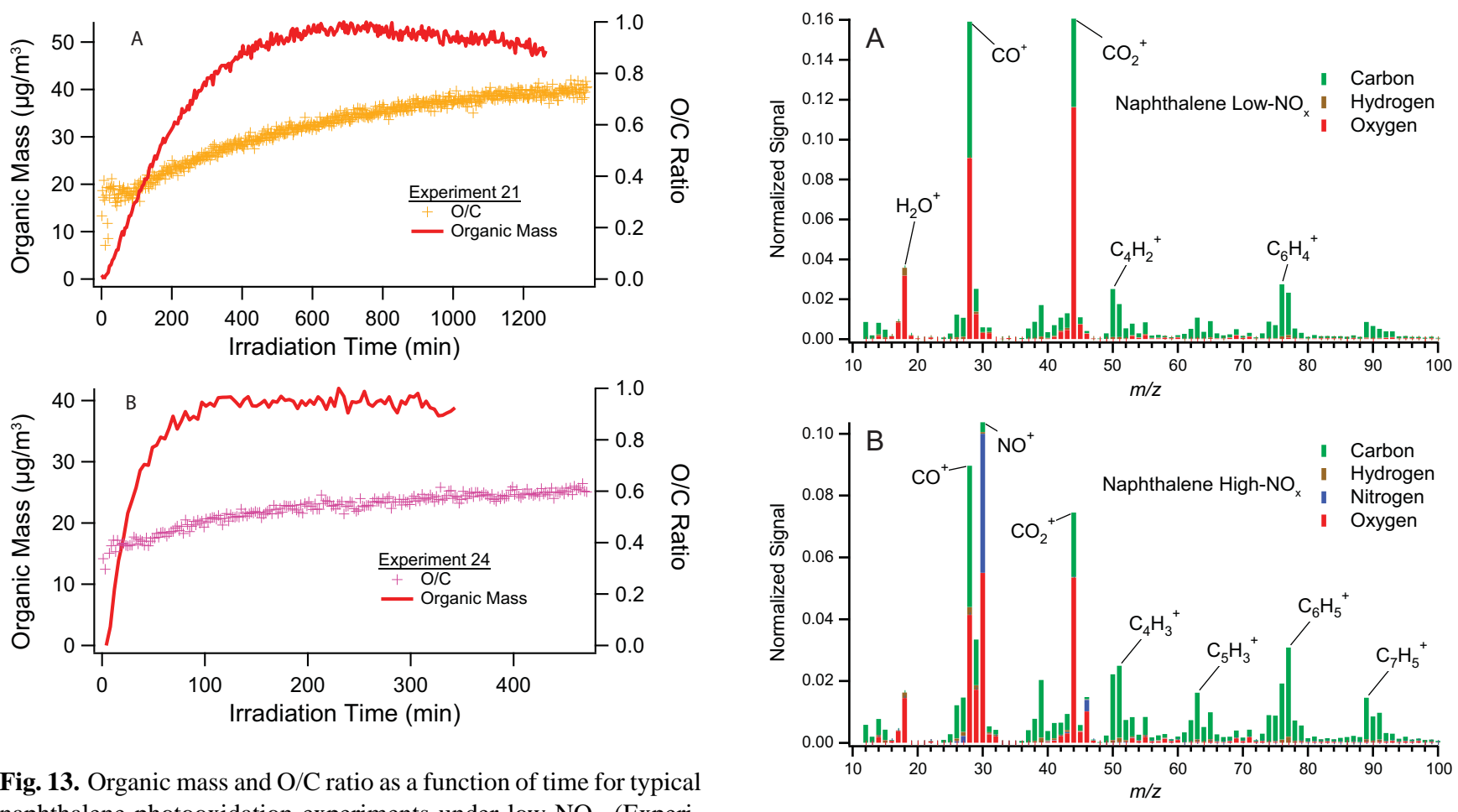

Fig. 13. Organic mass and $\mathrm{O} / \mathrm{C}$ ratio as a function of time for typical naphthalene photooxidation experiments under low- $\mathrm{NO}_{\mathrm{x}}$ (Experiment 21, A) and high- $\mathrm{NO}_{\mathrm{x}}$ (Experiment 24, B) conditions. Mass loadings are calculated by multiplying the change in DMA volume by an estimated density (Chan et al., 2009a).

2010). These compounds initially give isoprene-SOA high $\mathrm{O} / \mathrm{C}$ values, but due to photolysis or oligomerization reactions, the $\mathrm{O} / \mathrm{C}$ ratio decreases. This behavior is in contrast to the behavior of single-ringed aromatic and naphthalene$\mathrm{SOA}$, in which the $\mathrm{O} / \mathrm{C}$ ratios tend to increase with time. SOA from isoprene photooxidation under high- $\mathrm{NO}_{\mathrm{x}}$ conditions is predominantly comprised of 2-methylglyceric acid and its corresponding oligoesters (Surratt et al., 2006, 2010; Szmigielski et al., 2007). However, O/C and H/C ratios remain constant over the course of oxidation.

Table 3 lists the O/C values of various laboratory SOA systems as determined by different mass spectrometry methods. As in this study, Aiken et al. (2008) used the AMS to measure the elemental composition of chamber SOA in several systems; the O/C values of SOA from the photooxidation of comparable VOCs tend to be higher in the experiments considered in the present study. The exact reason for this disparity is unclear but could be a result of several factors, including differences in $\mathrm{OH}$ sources, amounts of organic mass, and extents of reaction. Other studies of monoterpene-derived $\mathrm{SOA}$ tend to yield similar $\mathrm{O} / \mathrm{C}$ values. Although only $\mathrm{O} / \mathrm{C}$ ratios are presented in Table 3, measured $\mathrm{OM} / \mathrm{OC}$ ratios are similar to those found in other studies as well (Kleindienst et al., 2007, 2009).

Fig. 14. High-resolution mass spectra of naphthalene-SOA formed under low- $\mathrm{NO}_{\mathrm{x}}(\mathbf{A})$ and high- $\mathrm{NO}_{\mathrm{x}}(\mathbf{B})$ conditions with elemental contributions to each mass-to-charge ratio shown. Spectra were taken at the peak of SOA growth.

\subsection{Comparisons with offline analytical techniques}

The elemental ratios measured by the HR-ToF-AMS can be compared to those of compounds detected by offline analytical techniques, such as coupled chromatography/mass spectrometry of filter extractions. For systems for which the majority of the SOA mass can be quantified by offline advanced analytical techniques, the elemental composition of both measurement techniques can be compared and validated. For $\alpha$-pinene $/ \mathrm{O}_{3}$ and naphthalene photooxidation SOA, a substantial portion of the total organic mass has been identified and quantified by coupled gas or liquid chromatography/mass spectrometry (GC/MS or LC/MS) methods and iodometric-spectrophotometric techniques (Yu et al., 1999; Docherty et al., 2005; Kautzman et al., 2010). The discrepancy between the $\alpha$-pinene ozonolysis products measured by Yu et al. (1999) and Docherty et al. (2005) could be due to the reactive nature of organic peroxides which decompose to the products measured by gas chromatography. However, the elemental ratios of the products suggested by Docherty et al. (2005) and the mole-weighted calculations of $\mathrm{H} / \mathrm{C}, \mathrm{O} / \mathrm{C}$ and $\mathrm{N} / \mathrm{C}$ ratios of the quantified species in Yu et al. (1999) are very close to the measured elemental composition of the HR-ToF-AMS. In contrast, quantification of many of the particle-phase constituents of isoprene, 
toluene, and $m$-xylene photooxidation in both $\mathrm{NO}_{\mathrm{x}}$ regimes has been difficult to achieve. For isoprene photooxidation, Surratt et al. (2006) were able to quantify roughly $20 \%$ of the SOA mass formed under high- $\mathrm{NO}_{\mathrm{x}}$ conditions and $30 \%$ under low- $\mathrm{NO}_{\mathrm{x}}$ conditions. These measurements, however, have associated uncertainties. Because exact standards were not available, acidic species formed under high- $\mathrm{NO}_{\mathrm{x}}$ conditions were quantified using surrogate standards. In addition, peroxides formed under low- $\mathrm{NO}_{\mathrm{x}}$ conditions were quantified using a surrogate with a molecular weight close to the average molecular weight determined from mass spectrometry techniques. Quantification of compounds in aromaticSOA has been difficult as well, though much of the mass has been attributed to small organic acids (Kalberer et al., 2004; Fisseha et al., 2004). Despite the lack of mass closure, the elemental ratios determined by the HR-ToF-AMS can be compared to the compounds identified from these speciation studies. As noted earlier, the AMS-derived O/C ratios of isoprene and aromatic SOA tend to be lower than those of representative compounds identified by coupled chromatography/mass spectrometry. One possible reason for this difference is the extensive oligomerization present in the particle phase of both systems. Isoprene-SOA formed under both low- and high- $\mathrm{NO}_{\mathrm{x}}$ conditions has been found to form high-MW compounds, either by oligomerization or organosulfate formation (Surratt et al., 2006, 2007, 2010; Szmigielski et al., 2007). For example, Surratt et al. (2006) estimated that 2-methylglyceric acid and its corresponding oligoesters comprise $22-34 \%$ of the high- $\mathrm{NO}_{\mathrm{x}}$ SOA mass. In addition, Kalberer et al. (2004) found that about 50\% of the trimethylbenzene SOA mass was oligomeric, possibly from the particle-phase reactions of small acids (Fisseha et al., 2004). Esterification, aldol condensation, and hemiacetal/acetal formation reactions have been implicated in producing oligomers. Esterification and aldol condensation reactions, however, release $\mathrm{H}_{2} \mathrm{O}$ which can evaporate to the gas-phase which may occur under low RH conditions. Through VTDMA measurements, Dommen et al. (2006) found that under dry conditions, isoprene SOA volatility is suppressed, implying an enhancement of oligomerization at lower relative humidity. Removal of $\mathrm{H}_{2} \mathrm{O}$ will give lower $\mathrm{O} / \mathrm{C}$ and $\mathrm{H} / \mathrm{C}$ ratios measured by the AMS when compared to the monomers measured through chromatography. Substantial oligomerization has also been observed in $\alpha$-pinene $/ \mathrm{O}_{3}$ SOA by Gao et al. (2004); however, the relatively low oxygenation of the SOA likely restrains condensation reactions. Thus the O/C ratios of the first generation SOA products are a good representation of the bulk SOA as measured by the AMS. Kautzman et al. (2010) observed no oligomerization in naphthalene-SOA, hence condensation reactions are likely non-existent which allows the elemental ratios measured by the AMS likely represent the individual species detected through filter sampling. Artifacts of chromatographic separation may also lead to a bias in the detection of oligomers (Hallquist et al., 2009). Because of the reversibility of con- densation reactions, oligomers can hydrolyze, increasing the oxygenation of the species detected. Double-bonds can also hydrate, further increasing the $\mathrm{O} / \mathrm{C}$ ratio of detected compounds. Further work is needed in characterizing the extent of oligomerization in SOA.

\subsection{Uncertainty in the AMS elemental analysis}

Uncertainties in the AMS elemental analysis method contributing to discrepancies in elemental ratios arise from two main sources: variations in the ionization and fragmentation of compounds in the AMS and errors in analysis of highresolution mass spectra. To first order, the efficiency with which a molecule is ionized is proportional to the mass of the molecule. However, variations in the efficiencies at which fragment ions are detected occur due to the identity and structure of the molecule being ionized. For instance, uncorrected $\mathrm{O} / \mathrm{C}$ measurements tend to be biased low due to the propensity of oxygen-containing fragments to be neutral and therefore undetected (Aiken et al., 2007). As a result, the raw measurement of elemental ratios requires calibration factors derived from the analysis of laboratory standards. The uncertainty stated in Aiken et al. (2008) represents the average absolute value of the relative error of the individual data points with respect to the regression between measured elemental ratios and true elemental ratios of the laboratory standards. The uncertainty estimates for $\mathrm{O} / \mathrm{C}, \mathrm{H} / \mathrm{C}, \mathrm{N} / \mathrm{C}$, and OM/OC are $31 \%, 10 \%, 22 \%$, and $6 \%$, respectively. Since the uncertainty is an average for pure standards, Aiken et al. (2008) suggest it represents an upper bound to the uncertainty of measurements of complex mixtures of organic aerosol. Many of those standards are large alkanols and alkanoic acids or aromatic species, which are quite similar to the compounds detected in $\alpha$-pinene and naphthalene SOA. By contrast, few of the standards have structures similar to the species found in glyoxal, isoprene, and aromatic SOA such as polyols, peroxides, small organic acids, or larger oligoesters. Thus the calibration factor for an individual compound or class of species like glyoxal may be very different than those determined by Aiken et al. (2008). For instance the O/C calibration factor for glyoxal is likely within a factor of two of the Aiken factor since the upperbound $\mathrm{O} / \mathrm{C}$ is likely $2(\mathrm{O} / \mathrm{C}$ of hydrated glyoxal monomer), and the average measurement is 1.13. As more standards become available or as methods to measure hard to sample species are developed, the calibration factors should be revised to reflect ambient OA.

Recent studies have investigated the ability of AMS elemental analysis methods to measure the elemental composition of organonitrates. Farmer et al. (2010) studied AMS high-resolution measurements of organonitrate standards and mixtures and found that most of the nitrogen signal originates from $\mathrm{NO}_{\mathrm{x}}{ }^{+}$ions. Elemental analysis of these standards underestimated the $\mathrm{O} / \mathrm{C}, \mathrm{H} / \mathrm{C}$, and $\mathrm{N} / \mathrm{C}$ ratios though usually within the aforementioned uncertainties. Farmer et al. (2010) found that the underestimation in $\mathrm{O} / \mathrm{C}$ was approximately 
equivalent to assuming that the AMS detects all oxygen except the oxygen in the $\mathrm{NO}_{2}$ group. In the systems considered here, the effect of the inclusion of NO family ions to the O/C measurement varies across VOC type. Inclusion of these ions increases the measured $\mathrm{O} / \mathrm{C}$ of $m$-xylene SOA formed under high- $\mathrm{NO}_{\mathrm{x}}$ conditions by approximately $20 \%$, the largest contribution for all systems investigated. In a separate study, Rollins et al. (2010) synthesized four organonitrates similar in structure to oxidation products of common atmospheric VOCs and measured them with an AMS. It was found that while nitrogen was detected at a higher efficiency than previous standards, oxygen was detected at a much lower efficiency than Aiken et al. (2008). Therefore, both studies suggest that the $\mathrm{O} / \mathrm{C}$ ratios measured for high- $\mathrm{NO}_{\mathrm{x}}$ photooxidation experiments are biased low partly because of the inability of the AMS to efficiently detect oxygen in an organic nitrate group. Rollins et al. (2010) estimated a correction to measured $\mathrm{O} / \mathrm{C}$ ratios as follows:

$$
\left(\frac{O}{C}\right)_{\text {true }}=\left(\frac{O}{C}\right)_{\text {rep }}+1.5\left(\frac{N}{C}\right)_{\text {rep }}
$$

where "true" corresponds to the actual elemental ratio of the aerosol, and "rep" corresponds to ratios determined using traditional correction factors. Given that the maximum N/C ratios for high- $\mathrm{NO}_{\mathrm{x}}$ photooxidation systems in this study vary from 0.06 to 0.10 , the additional correction to $\mathrm{O} / \mathrm{C}$ ratios ranges from 0.09 to 0.15 . While this is not enough to account for the disparity between measured AMS O/C ratios and those of identified SOA species from high- $\mathrm{NO}_{\mathrm{x}}$ isoprene experiments, it does provide an explanation as to why AMS $\mathrm{O} / \mathrm{C}$ measurements might be biased low.

Apart from ionization and fragmentation variations, errors in the analysis of high-resolution mass spectra can also contribute to the uncertainty of measured elemental ratios. For instance, it is crucial that the $\mathrm{m} / \mathrm{z}$ calibration and peak shapes determined from a high-resolution dataset are accurate. Small deviations in the parameters for either of those determinations can lead to significant errors in the relative ratios of ion signals with the same mass-to-charge ratio or the erroneous existence of ions that lie near other ions with large signals. This becomes especially important at low organic loadings and when analyzing relatively lower resolution V-mode data. Across all systems studied here, elemental analysis of V-mode data consistently produced lower $\mathrm{O} / \mathrm{C}$ ratios than that of $\mathrm{W}$-mode data by 2 to $27 \%$ when the same set of ions were used. This disparity is almost completely due to an imperfect peak shape at $\mathrm{N}_{2}{ }^{+}$producing artificially large contributions for nearby $\mathrm{C}_{2} \mathrm{H}_{4}{ }^{+}$at $m / z$ 28. In W-mode, these ions are significantly resolved so that their peaks do not interfere and the removal of $\mathrm{C}_{2} \mathrm{H}_{4}{ }^{+}$from $\mathrm{V}$-mode data allows for near agreement of $\mathrm{O} / \mathrm{C}$ ratios between both modes of operation. It is recommended that the $\mathrm{C}_{2} \mathrm{H}_{4}{ }^{+}$be removed or estimated when performing elemental analysis of $\mathrm{V}$-mode data.
Inclusion of various ions whose signals might not completely be due to organic aerosol mass may also add to measurement uncertainty. For instance, it is possible that the default treatment of $\mathrm{O}^{+}, \mathrm{OH}^{+}$and $\mathrm{H}_{2} \mathrm{O}^{+}$ions may be inappropriate for glyoxal-SOA. The glyoxal uptake experiments were carried out at relative humidities of at least $60 \%$ so as to produce moist ammonium sulfate seed aerosol. Particlephase water plays an integral role in promoting uptake and oligomerization through hydration, likely leading to larger organic signals at $\mathrm{O}^{+}, \mathrm{OH}^{+}$and $\mathrm{H}_{2} \mathrm{O}^{+}$. The contributions of these ions are based on the $\mathrm{CO}_{2}{ }^{+}$organic signal, which is very low for glyoxal-SOA, possibly contributing to an underestimate of $\mathrm{H} / \mathrm{C}$ and $\mathrm{O} / \mathrm{C}$ ratios. Underestimates in elemental ratios may also be a result of the exclusion of "NH family" ions and "SO family" ions. These ions were not included as part of the organic mass because most of their signals could be attributed to ammonium sulfate seed aerosol. Yet, various studies have shown that inorganic constituents of aerosol may react with organics to form new species (Hallquist et al., 2009). For example, Galloway et al. (2009) demonstrated the formation of reduced nitrogen-containing compounds, particularly imidazoles, from a proposed reaction of ammonium and glyoxal while organonitrate standards have been shown to produce $\mathrm{NH}_{\mathrm{x}}{ }^{+}$fragments (Rollins et al., 2010). Other studies have observed organosulfates $\left(\mathrm{R}-\mathrm{OSO}_{3}\right)$, organonitrates, and nitrated organosulfates in SOA produced from the photooxidation of isoprene in the presence of ammonium sulfate seed (Surratt et al., 2006, 2007, 2010). Kautzman et al. (2010) observed hydroxybenzene sulfonic acid in naphthalene SOA in both high and low- $\mathrm{NO}_{\mathrm{x}}$ regimes and most recent investigations of organosulfate standards show that these compounds tend to fragment into SO family ions (Farmer et al., 2010). Thus exclusion of these ions will negatively bias $\mathrm{N} / \mathrm{C}, \mathrm{H} / \mathrm{C}, \mathrm{O} / \mathrm{C}$, and $\mathrm{S} / \mathrm{C}$ values. S/C ratios were considered zero, as no sulfur-containing ions were measured apart from SO family ions.

\subsection{AMS marker ions and SOA oxygenation}

Analysis of the elemental contributions of different AMS marker ions can provide insight into the possible bulk chemistry occurring in the particle phase. In the oxidative systems studied here ( $\alpha$-pinene, isoprene, single-ring aromatics, and naphthalene), the ions $\mathrm{C}_{2} \mathrm{H}_{3} \mathrm{O}^{+}$and $\mathrm{CO}_{2}{ }^{+}$at $\mathrm{m} / z 43$ and 44 , respectively, contribute strongly to the oxygen content of the formed SOA. In past AMS studies, $\mathrm{C}_{2} \mathrm{H}_{3} \mathrm{O}^{+}$is prominent in freshly oxidized SOA while $\mathrm{CO}_{2}{ }^{+}$appears strongly in the spectra of aged OA and laboratory standards of organic acids (Takegawa et al., 2007; Zhang et al., 2005a, 2007; Ulbrich et al., 2009). The spectra presented in the current experiments support these general observations, as the $\mathrm{C}_{2} \mathrm{H}_{3} \mathrm{O}^{+}$ signal is relatively prominent early in the experiments but its fraction of the total organic signal decreases as that of $\mathrm{CO}_{2}{ }^{+}$ increases. In a recent study by Kroll et al. (2009) of heterogeneously oxidized squalane particles, the initial increase of 


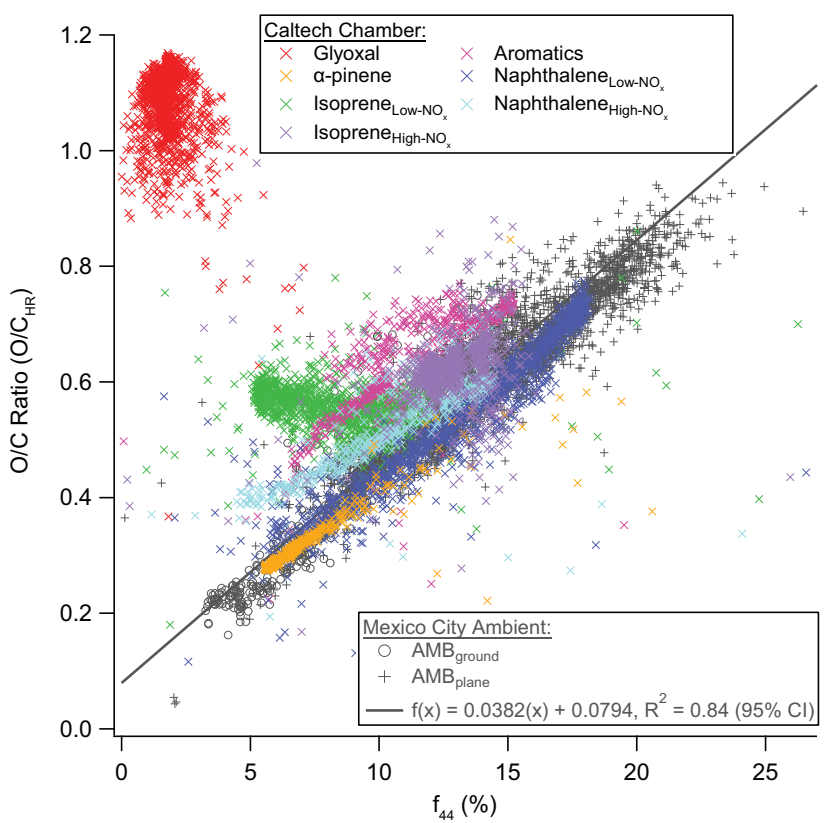

Fig. 15. $\mathrm{O} / \mathrm{C}_{\mathrm{HR}}$ vs. $\mathrm{f}_{44}$ for ambient Mexico City OA (Aiken et al., 2008, Fig. 4) and chamber OA. The solid line represents the correlation derived from ambient data. Experiments 19, 22, and 26 are not shown for simplicity.

$\mathrm{C}_{2} \mathrm{H}_{3} \mathrm{O}^{+}$signal was associated with functionalization reactions, those that add oxygen to the carbon chain. With further oxidation, the $\mathrm{CO}_{2}{ }^{+}$signal increased, which was associated with fragmentation reactions, those associated with C-C bond scission and subsequent loss of relatively small carbon fragments. It is likely that such processes are occurring, either heterogeneously or in the gas phase, in the systems evaluated here, especially for the single-ring aromatic and naphthalene systems where the $\mathrm{O} / \mathrm{C}$ ratio continues to increase even as the total particulate volume decreases (Fig. 13 for example). Although time-dependent densities were not measured and wall losses may contribute to the declining particulate volume, it is likely that the continued $\mathrm{O} / \mathrm{C}$ increase is occurring through fragmentation reactions that are removing carbon from the particle phase. More study is needed to elucidate the contributions of functionalization and fragmentation pathways of SOA.

Recently Aiken et al. (2008) derived a correlation (Eq. 4) between $\mathrm{f}_{44}$, the fraction of organic signal at $\mathrm{m} / \mathrm{z} 44$ and the $\mathrm{O} / \mathrm{C}$ measured from the elemental analysis method. Using this correlation, we can evaluate the extent to which $\mathrm{f}_{44}$ captures the relative oxygenation of SOA formed in chamber studies. This correlation along with ambient Mexico City data and data from the systems evaluated here are shown in Fig. 15. Supplemental Figs. S1, S3, S4, and S6-S9 (http://www.atmos-chem-phys.net/10/4111/ 2010/acp-10-4111-2010-supplement.pdf) compare O/C $\mathrm{HR}$ to $\mathrm{O} / \mathrm{C}_{44}$ for each system as a function of time. For most

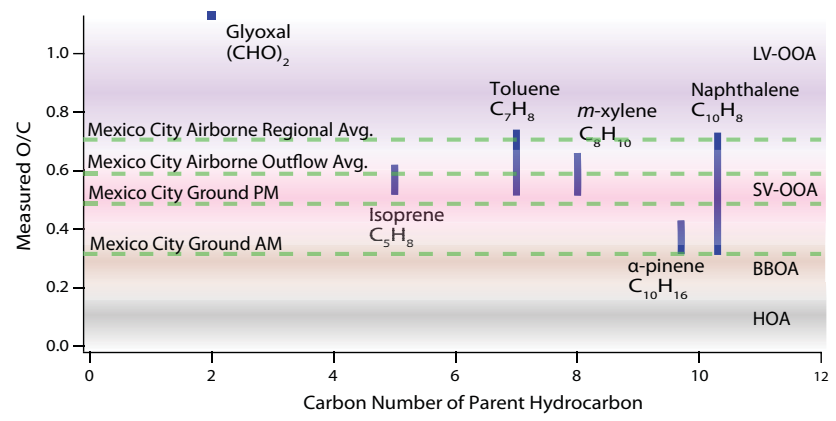

Fig. 16. O/C ratios for ambient Mexico City organic aerosol (Aiken et al., 2008), typical AMS components derived from positive matrix factorization (PMF) (Aiken et al., 2008, 2009; Ulbrich et al., 2009; Zhang et al., 2005b), and chamber SOA as a function of precursor carbon number. Ranges for each precursor represent the total O/C range achieved in the experiments surveyed here. Shaded regions represent the typically prescribed O/C ranges for AMS PMF components and can vary depending on the ambient data set.

oxidant/precursor systems, $\mathrm{O} / \mathrm{C}_{44}$ mimics the overall trend of $\mathrm{O} / \mathrm{C}_{\mathrm{HR}}$ well. For the $\alpha$-pinene $/ \mathrm{O}_{3}$, isoprene/high- $\mathrm{NO}_{\mathrm{x}}$, and naphthalene SOA systems, the close correspondence of $\mathrm{O} / \mathrm{C}_{44}$ and $\mathrm{O} / \mathrm{C}_{\mathrm{HR}}$ results because $\mathrm{CO}_{2}{ }^{+}$provides much of the oxygen signal in the spectra. For the single ring aromatic systems, $\mathrm{O} / \mathrm{C}_{44}$ is consistently below $\mathrm{O} / \mathrm{C}_{\mathrm{HR}}$ but trends with it. For the isoprene/low- $\mathrm{NO}_{\mathrm{x}}$ system, $\mathrm{O} / \mathrm{C}_{44}$ underestimates $\mathrm{O} / \mathrm{C}_{\mathrm{HR}}$ by $50 \%$ early in the oxidation, but then increases to meet $\mathrm{O} / \mathrm{C}_{\mathrm{HR}}$. For these systems, other mass fragments, especially $m / z, 43\left(\mathrm{C}_{2} \mathrm{H}_{3} \mathrm{O}^{+}\right)$, contribute a large part of the oxygen content. As the contribution of $m / z 44$ grows in these experiments, $\mathrm{O} / \mathrm{C}_{44}$ becomes a better surrogate for $\mathrm{O} / \mathrm{C}_{\mathrm{HR}}$. Glyoxal-SOA is a special case because $\mathrm{CO}_{2}{ }^{+}$represents less than $1 \%$ of the total organic signal. Although hydrated glyoxal and its oligomers are highly oxygenated, they do not contain acid groups that can easily fragment into $\mathrm{CO}_{2}{ }^{+}$. Thus $m / z, 44$ is a poor surrogate for estimating the oxygen content of glyoxal SOA. In general, $m / z 44$ adequately represents the oxygenation of SOA in different oxidative systems, especially for more aged SOA, and for SOA where $m / z 44$ has the largest contribution to the spectral signal. In the ambient atmophere, $\mathrm{m} / \mathrm{z}, 44$ and the correlation determined by Aiken et al. (2008) may better reflect the oxygen content of SOA because ambient SOA represents a very large mixture of compounds from many different VOCs whereas chamber SOA is relatively more homogeneous.

\section{Comparison of chamber and ambient elemental ratios and spectra}

Figure 16 shows the range of $\mathrm{O} / \mathrm{C}$ ratios determined from the set of chamber experiments evaluated here, as compared with ambient O/C measurements of Mexico City SOA. Chamber $\mathrm{SOA} \mathrm{O} / \mathrm{C}$ ratios are plotted as a function of precursor carbon 
number, and the bars represent the maximum range of $\mathrm{O} / \mathrm{C}$ values observed for each VOC precursor. The dotted lines represent the average $\mathrm{O} / \mathrm{C}$ values for different sampling times and areas in Mexico City (Aiken et al., 2008), showing that the $\mathrm{O} / \mathrm{C}$ ratios increase with photochemical age. The shaded regions depict the range of $\mathrm{O} / \mathrm{C}$ ratios commonly attributed to the different PMF components found for various ambient data sets (Aiken et al., 2008, 2009; Ulbrich et al., 2009; Zhang et al., 2005a,b, 2007), including oxygenated organic aerosol (OOA), biomass burning organic aerosol (BBOA), and hydrocarbon-like organic aerosol (HOA). These ranges and factors are not definite for all ambient data sets but typify the oxygenation domains for commonly derived PMF factors. Often, the OOA is found to consist of two factors: the LV-OOA PMF component is considered to represent aged organic aerosol with a higher $\mathrm{O} / \mathrm{C}$ ratio than $\mathrm{SV}$-OOA which is considered to represent relatively fresh SOA.

While one might expect SOA O/C ratios to decrease as the carbon number of the precursor system increases, individual differences in elemental composition depend greatly on the identity of the precursor and mechanism, and the duration of oxidation. In the experiments surveyed here, photooxidation of aromatic precursor systems (toluene, $m$-xylene, and naphthalene) produces SOA that achieves higher $\mathrm{O} / \mathrm{C}$ ratios than the biogenic systems (isoprene photooxidation and $\alpha$-pinene ozonolysis). While this is not necessarily representative of ambient SOA formation, it does provide context to compare the $\mathrm{SOA} \mathrm{O} / \mathrm{C}$ ratios measured in ambient atmosphere to those from chamber experiments. Previous studies have noted that AMS mass spectra of chamber data do not exhibit as much oxidation as the OOA mass spectrum, with the possible exception of SOA derived from aromatic precursors (Zhang et al., 2005a; Bahreini et al., 2005). The laboratory data evaluated here show that for photooxidation-SOA, O/C ratios of at least 0.5 are achieved, an oxidation state comparable to that of SV-OOA. Aromatic and naphthalene photooxidation yield SOA that increases in $\mathrm{O} / \mathrm{C}$ ratios throughout the experiments, regardless of $\mathrm{NO}_{\mathrm{x}}$ condition, reaching upwards of 0.7 , well into what might be considered as the oxygenation state of LV-OOA. Generally chamber studies do not reach the highest $\mathrm{O} / \mathrm{C}$ ratios observed in remote $\mathrm{OA}$, which can approach unity (DeCarlo et al., 2008). This emphasizes the need to devise chamber experiments that achieve sufficient timescales to achieve the $\mathrm{OH}$ exposure needed to form the most oxygenated SOA (Hallquist et al., 2009).

In addition to elemental composition, comparisons between PMF component spectra and chamber spectra from the AMS can provide insight into the extent to which chamber systems represent ambient SOA. The typical HOA spectrum is identified by its $\mathrm{C}_{\mathrm{n}} \mathrm{H}_{2 \mathrm{n}+1}{ }^{+}$and $\mathrm{C}_{\mathrm{n}} \mathrm{H}_{2 \mathrm{n}-1}{ }^{+}$ion series, characteristic of hydrocarbon spectra. On the other hand, the OOA spectrum is distinguished by a strong peak at $m / z, 44$ $\left(\mathrm{CO}_{2}{ }^{+}\right)$and relatively little signal at $m / z>55$. In its subclasses, SV-OOA has a prominent $m / z, 43\left(\mathrm{C}_{2} \mathrm{H}_{3} \mathrm{O}^{+}\right)$signal, and LV-OOA has a dominant $m / z 44$ signal. Of the systems surveyed here, aromatic (toluene, $m$-xylene, and naphthalene) and isoprene high- $\mathrm{NO}_{\mathrm{x}}$ spectra most resemble that of OOA, with prominent contributions at $\mathrm{C}_{2} \mathrm{H}_{3} \mathrm{O}^{+}$and $\mathrm{CO}_{2}{ }^{+}$ and relatively small signals at higher mass-to-charge ratios. Naphthalene spectra best resemble LV-OOA with a dominant $\mathrm{m} / \mathrm{z} 44$ signal; they do, however, have fairly sizable signals at hydrocarbon-like ions, likely from the fragmentation of a retained aromatic ring. The spectra of $m$-xylene, toluene and isoprene-high- $\mathrm{NO}_{\mathrm{x}}$ resemble that of SV-OOA with strong contributions at $\mathrm{C}_{2} \mathrm{H}_{3} \mathrm{O}^{+}$. The steady increase of $\mathrm{f}_{44}$ throughout the duration of single-ring aromatic photooxidation suggests that with continued irradiation the spectra will look more like that of LV-OOA. Consistent with measured $\mathrm{O} / \mathrm{C}$ ratios, the spectrum of SOA from $\alpha$-pinene ozonolysis is the least oxidized; along with a prominent $\mathrm{C}_{2} \mathrm{H}_{3} \mathrm{O}^{+}$contribution, the spectrum shown in Fig. $2 \mathrm{~b}$ has considerable signals of hydrocarbon-like ions in series similar to that of HOA. One should note that the organic loadings for the $\alpha$-pinene system were relatively large, and that at smaller loadings the spectrum will be more similar to that of OOA (Shilling et al., 2009). Interestingly, the spectrum of the most oxidized system, glyoxal uptake, least resembles the spectra of previously identified PMF components. The dominant $\mathrm{CHO}^{+}$ion and other notable ions that exist in the valleys of typical ions series, such as $\mathrm{CH}_{3} \mathrm{O}_{2}{ }^{+}$and $\mathrm{C}_{2} \mathrm{H}_{2} \mathrm{O}_{2}{ }^{+}$, in the glyoxal-SOA spectrum suggest that if glyoxal uptake is occurring to a significant extent in ambient systems, these ions would be prominent in ambient spectra; they do appear in OOA spectra (Aiken et al., 2009, Sup. Matl.) but not at the percent of the total spectral signal observed here. If reactive uptake of glyoxal occurs substantially in ambient SOA, its contribution to AMS spectra may be obscured by the presence of other species or by its participation in particle-phase reactions.

The work here presents high resolution AMS data of a canonical ensemble of chamber SOA systems. While not representing the most oxidized ambient SOA, the spectra and elemental composition measurements of the surveyed systems could provide a basis for linking chamber data to ambient measurements and understanding ambient PMF factors, especially the SV-OOA component. However, more work is needed to correlate AMS spectra with molecular structure, and experiments need to be devised that can reach the oxidation states achieved in ambient systems to further interpret the the full transformation of VOCs to OOA.

Acknowledgements. This work was supported by the US Department of Energy Biological and Environmental Research grant DEFG02-05ER63983, US Environmental Protection Agency STAR grant RD-83374901, and US NSF grant ATM-0432377. It has not been formally reviewed by EPA. The views expressed in this document are solely those of the authors and the EPA does not endorse any products in this publication. The authors would like to thank Arthur Chan, Jason Surratt and Nga Lee Ng for helpful discussions and Man Nin Chan for analysis of filter samples. 
Edited by: J.-L. Jimenez

\section{References}

Aiken, A. C., DeCarlo, P. F., and Jimenez, J. L.: Elemental analysis of organic species with electron ionization highresolution mass spectrometry, Anal. Chem., 79, 8350-8358, doi:10.1021/Ac071150w, 2007.

Aiken, A. C., Decarlo, P. F., Kroll, J. H., Worsnop, D. R., Huffman, J. A., Docherty, K. S., Ulbrich, I. M., Mohr, C., Kimmel, J. R., Sueper, D., Sun, Y., Zhang, Q., Trimborn, A., Northway, M., Ziemann, P. J., Canagaratna, M. R., Onasch, T. B., Alfarra, M. R., Prevot, A. S. H., Dommen, J., Duplissy, J., Metzger, A., Baltensperger, U., and Jimenez, J. L.: O/C and OM/OC ratios of primary, secondary, and ambient organic aerosols with high-resolution time-of-flight aerosol mass spectrometry, Environ. Sci. Technol., 42, 4478-4485, doi:10.1021/Es703009q, 2008.

Aiken, A. C., Salcedo, D., Cubison, M. J., Huffman, J. A., DeCarlo, P. F., Ulbrich, I. M., Docherty, K. S., Sueper, D., Kimmel, J. R., Worsnop, D. R., Trimborn, A., Northway, M., Stone, E. A., Schauer, J. J., Volkamer, R. M., Fortner, E., de Foy, B., Wang, J., Laskin, A., Shutthanandan, V., Zheng, J., Zhang, R., Gaffney, J., Marley, N. A., Paredes-Miranda, G., Arnott, W. P., Molina, L. T., Sosa, G., and Jimenez, J. L.: Mexico City aerosol analysis during MILAGRO using high resolution aerosol mass spectrometry at the urban supersite (T0) - Part 1: Fine particle composition and organic source apportionment, Atmos. Chem. Phys., 9, 66336653, 2009, http://www.atmos-chem-phys.net/9/6633/2009/.

Allan, J. D., Delia, A. E., Coe, H., Bower, K. N., Alfarra, M. R., Jimenez, J. L., Middlebrook, A. M., Drewnick, F., Onasch, T. B., Canagaratna, M. R., Jayne, J. T., and Worsnopf, D. R.: A generalised method for the extraction of chemically resolved mass spectra from aerodyne aerosol mass spectrometer data, J. Aerosol Sci., 35, 909-922, doi:10.1016/j.jaerosci.2004.02.007, 2004.

Alvarez, E. G., Viidanoja, J., Munoz, A., Wirtz, K., and Hjorth, J.: Experimental confirmation of the dicarbonyl route in the photooxidation of toluene and benzene, Environ. Sci. Technol., 41, 8362-8369, doi:10.1021/Es0713274, 2007.

Atkinson, R., Aschmann, S. M., Arey, J., Zielinska, B., and Schuetzle, D.: Gas-phase atmospheric chemistry of 1-Nitronaphthalene and 2-Nitronaphthalene and 1,4-Naphthoquinone, Atmos. Environ., 23, 2679-2690, 1989.

Bahreini, R., Keywood, M. D., Ng, N. L., Varutbangkul, V., Gao, S., Flagan, R. C., Seinfeld, J. H., Worsnop, D. R., and Jimenez, J. L.: Measurements of secondary organic aerosol from oxidation of cycloalkenes, terpenes, and $m$-xylene using an Aerodyne aerosol mass spectrometer, Environ. Sci. Technol., 39, 5674-5688, doi:10.1021/Es048061a, 2005.

Bloss, C., Wagner, V., Jenkin, M. E., Volkamer, R., Bloss, W. J., Lee, J. D., Heard, D. E., Wirtz, K., Martin-Reviejo, M., Rea, G., Wenger, J. C., and Pilling, M. J.: Development of a detailed chemical mechanism (MCMv3.1) for the atmospheric oxidation of aromatic hydrocarbons, Atmos. Chem. Phys., 5, 641-664, 2005, http://www.atmos-chem-phys.net/5/641/2005/.

Canagaratna, M. R., Jayne, J. T., Jimenez, J. L., Allan, J. D., Alfarra, M. R., Zhang, Q., Onasch, T. B., Drewnick, F., Coe, H., Middlebrook, A., Delia, A., Williams, L. R., Trimborn, A. M., Northway, M. J., DeCarlo, P. F., Kolb, C. E., Davidovits, P., and
Worsnop, D. R.: Chemical and microphysical characterization of ambient aerosols with the aerodyne aerosol mass spectrometer, Mass Spectrom. Rev., 26, 185-222, doi:10.1002/Mas.20115, 2007.

Chan, A. W. H., Kautzman, K. E., Chhabra, P. S., Surratt, J. D., Chan, M. N., Crounse, J. D., Kürten, A., Wennberg, P. O., Flagan, R. C., and Seinfeld, J. H.: Secondary organic aerosol formation from photooxidation of naphthalene and alkylnaphthalenes: implications for oxidation of intermediate volatility organic compounds (IVOCs), Atmos. Chem. Phys., 9, 3049-3060, 2009a, http://www.atmos-chem-phys.net/9/3049/2009/.

Chan, M. N., Chan, A. W. H., Chhabra, P. S., Surratt, J. D., and Seinfeld, J. H.: Modeling of secondary organic aerosol yields from laboratory chamber data, Atmos. Chem. Phys., 9, 56695680, 2009b, http://www.atmos-chem-phys.net/9/5669/2009/.

Claeys, M., Graham, B., Vas, G., Wang, W., Vermeylen, R., Pashynska, V., Cafmeyer, J., Guyon, P., Andreae, M. O., Artaxo, P., and Maenhaut, W.: Formation of secondary organic aerosols through photooxidation of isoprene, Science, 303, 1173-1176, 2004.

Cocker, D. R., Flagan, R. C., and Seinfeld, J. H.: State-of-theart chamber facility for studying atmospheric aerosol chemistry, Environ. Sci. Technol., 35, 2594-2601, doi:10.1021/Es0019169, 2001.

Crable, G. F. and Coggeshall, N. D.: Application of total ionization principles to mass spectrometric analysis, Anal. Chem., 30, 310313, 1958.

DeCarlo, P. F., Kimmel, J. R., Trimborn, A., Northway, M. J., Jayne, J. T., Aiken, A. C., Gonin, M., Fuhrer, K., Horvath, T., Docherty, K. S., Worsnop, D. R., and Jimenez, J. L.: Fielddeployable, high-resolution, time-of-flight aerosol mass spectrometer, Anal. Chem., 78, 8281-8289, doi:10.1021/Ac061249n, 2006.

DeCarlo, P. F., Dunlea, E. J., Kimmel, J. R., Aiken, A. C., Sueper, D., Crounse, J., Wennberg, P. O., Emmons, L., Shinozuka, Y., Clarke, A., Zhou, J., Tomlinson, J., Collins, D. R., Knapp, D., Weinheimer, A. J., Montzka, D. D., Campos, T., and Jimenez, J. L.: Fast airborne aerosol size and chemistry measurements above Mexico City and Central Mexico during the MILAGRO campaign, Atmos. Chem. Phys., 8, 4027-4048, 2008, http://www.atmos-chem-phys.net/8/4027/2008/.

Docherty, K. S., Wu, W., Lim, Y. B., and Ziemann, P. J.: Contributions of organic peroxides to secondary aerosol formed from reactions of monoterpenes with $\mathrm{O}_{3}$, Environ. Sci. Technol., 39, 4049-4059, 2005.

Dommen, J., Metzger, A., Duplissy, J., Kalberer, M., Alfarra, M. R., Gascho, A., Weingartner, E., Prevot, A. S. H., Verheggen, B., and Baltensperger, U.: Laboratory observation of oligomers in the aerosol from isoprene/ $\mathrm{NO}_{\mathrm{x}}$ photooxidation, Geophys. Res. Lett., 33, L13805, doi:10.1029/2006g1026523, 2006.

Drewnick, F., Hings, S. S., DeCarlo, P., Jayne, J. T., Gonin, M., Fuhrer, K., Weimer, S., Jimenez, J. L., Demerjian, K. L., Borrmann, S., and Worsnop, D. R.: A new time-of-flight aerosol mass spectrometer (TOF-AMS) - instrument description and first field deployment, Aerosol Sci. Tech., 39, 637-658, doi:10.1080/02786820500182040, 2005.

Dzepina, K., Volkamer, R. M., Madronich, S., Tulet, P., Ulbrich, I. M., Zhang, Q., Cappa, C. D., Ziemann, P. J., and Jimenez, J. L.: Evaluation of recently-proposed secondary organic aerosol models for a case study in Mexico City, Atmos. Chem. Phys., 9, 
5681-5709, 2009,

http://www.atmos-chem-phys.net/9/5681/2009/.

Farmer, D. K., Matsunaga, A., Docherty, K. S., Surratt, J. D., Seinfeld, J. H., Ziemann, P. J., and Jimenez, J. L.: Response of an aerosol mass spectrometer to organonitrates and organosulfates and implications for atmospheric chemistry, Proc. Natl. Acad. Sci., doi:10.1073/pnas.0912340107, 2010.

Fisseha, R., Dommen, J., Sax, M., Paulsen, D., Kalberer, M., Maurer, R., Hofler, F., Weingartner, E., and Baltensperger, U.: Identification of organic acids in secondary organic aerosol and the corresponding gas phase from chamber experiments, Anal. Chem., 76, 6535-6540, doi:10.1021/Ac048975f, 2004.

Fratzke, A. R. and Reilly, P. J.: Thermodynamic and kineticanalysis of the dimerization of aqueous glyoxal, Int. J. Chem. Kinet., 18, 775-789, 1986.

Galloway, M. M., Chhabra, P. S., Chan, A. W. H., Surratt, J. D., Flagan, R. C., Seinfeld, J. H., and Keutsch, F. N.: Glyoxal uptake on ammonium sulphate seed aerosol: reaction products and reversibility of uptake under dark and irradiated conditions, Atmos. Chem. Phys., 9, 3331-3345, 2009,

http://www.atmos-chem-phys.net/9/3331/2009/.

Gao, S., Keywood, M., Ng, N. L., Surratt, J., Varutbangkul, V., Bahreini, R., Flagan, R. C., and Seinfeld, J. H.: Low-molecularweight and oligomeric components in secondary organic aerosol from the ozonolysis of cycloalkenes and alpha-pinene, J. Phys. Chem. A, 108, 10147-10164, doi:10.1021/Jp047466e, 2004.

Glasius, M., Lahaniati, M., Calogirou, A., Di Bella, D., Jensen, N. R., Hjorth, J., Kotzias, D., and Larsen, B. R.: Carboxylic acids in secondary aerosols from oxidation of cyclic monoterpenes by ozone, Environ. Sci. Technol., 34, 1001-1010, 2000.

Gómez-González, Y., Surratt, J. D., Cuyckens, F., Szmigielski, R., Vermeylen, R., Jaoui, M., Lewandowski, M., Offenberg, J. H., Kleindienst, T. E., Edney, E. O., Blockhuys, F., Van Alsenoy, C., Maenhaut, W., and Claeys, M.: Characterization of organosulfates from the photooxidation of isoprene and unsaturated fatty acids in ambient aerosol using liquid chromatography/(-) electrospray ionization mass spectrometry, J. Mass Spectrom., 43, 371-382, doi:10.1002/Jms.1329, 2008.

Hallquist, M., Wenger, J. C., Baltensperger, U., Rudich, Y., Simpson, D., Claeys, M., Dommen, J., Donahue, N. M., George, C., Goldstein, A. H., Hamilton, J. F., Herrmann, H., Hoffmann, T., Iinuma, Y., Jang, M., Jenkin, M. E., Jimenez, J. L., KiendlerScharr, A., Maenhaut, W., McFiggans, G., Mentel, T. F., Monod, A., Prévôt, A. S. H., Seinfeld, J. H., Surratt, J. D., Szmigielski, R., and Wildt, J.: The formation, properties and impact of secondary organic aerosol: current and emerging issues, Atmos. Chem. Phys., 9, 5155-5235, 2009,

http://www.atmos-chem-phys.net/9/5155/2009/.

Hamilton, J. F., Lewis, A. C., Bloss, C., Wagner, V., Henderson, A. P., Golding, B. T., Wirtz, K., Martin-Reviejo, M., and Pilling, M. J.: Measurements of photo-oxidation products from the reaction of a series of alkyl-benzenes with hydroxyl radicals during EXACT using comprehensive gas chromatography, Atmos. Chem. Phys., 3, 1999-2014, 2003, http://www.atmos-chem-phys.net/3/1999/2003/.

Hamilton, J. F., Webb, P. J., Lewis, A. C., and Reviejo, M. M.: Quantifying small molecules in secondary organic aerosol formed during the photo-oxidation of toluene with hydroxyl radicals, Atmos. Environ., 39, 7263-7275, doi:10.1016/j.atmosenv.2005.09.006, 2005.

Heaton, K. J., Dreyfus, M. A., Wang, S., and Johnston, M. V.: Oligomers in the early stage of biogenic secondary organic aerosol formation and growth, Environ. Sci. Technol., 41, 61296136, doi:10.1021/Es070314n, 2007.

Huffman, J. A., Docherty, K. S., Mohr, C., Cubison, M. J., U1brich, I. M., Ziemann, P. J., Onasch, T. B., and Jimenez, J. L.: Chemically-resolved volatility measurements of organic aerosol from different sources, Environ. Sci. Technol., 43, 5351-5357, doi:10.1021/Es803539d, 2009.

Iinuma, Y., Boge, O., Gnauk, T., and Herrmann, H.: Aerosolchamber study of the alpha-pinene/O-3 reaction: influence of particle acidity on aerosol yields and products, Atmos. Environ., 38, 761-773, doi:10.1016/j.atmosenv.2003.10.015, 2004.

Ip, H. S. S., Huang, X. H. H., and Yu, J. Z.: Effective Henry's law constants of glyoxal, glyoxylic acid, and glycolic acid, Geophys. Res. Lett., 36, L01802, doi:10.1029/2008g1036212, 2009.

Jang, M. and Kamens, R. M.: Newly characterized products and composition of secondary aerosols from the reaction of alphapinene with ozone, Atmos. Environ., 33, 459-474, 1999.

Jang, M. S. and Kamens, R. M.: Characterization of secondary aerosol from the photooxidation of toluene in the presence of $\mathrm{NO}_{\mathrm{x}}$ and 1-propene, Environ. Sci. Technol., 35, 3626-3639, doi:10.1021/Es010676+, 2001.

Jayne, J. T., Leard, D. C., Zhang, X. F., Davidovits, P., Smith, K. A., Kolb, C. E., and Worsnop, D. R.: Development of an aerosol mass spectrometer for size and composition analysis of submicron particles, Aerosol Sci. Tech., 33, 49-70, 2000.

Jimenez, J. L., Jayne, J. T., Shi, Q., Kolb, C. E., Worsnop, D. R., Yourshaw, I., Seinfeld, J. H., Flagan, R. C., Zhang, X. F., Smith, K. A., Morris, J. W., and Davidovits, P.: Ambient aerosol sampling using the Aerodyne Aerosol Mass Spectrometer, J. Geophys. Res.-Atmos., 108(D7), 8425, doi:10.1029/2001jd001213, 2003.

Jimenez, J. L., Canagaratna, M. R., Donahue, N. M., Prevot, A. S. H., Zhang, Q., Kroll, J. H., DeCarlo, P. F., Allan, J. D., Coe, H., Ng, N. L., Aiken, A. C., Docherty, K. D., Ulbrich, I. M., Grieshop, A. P., Robinson, A. L., Duplissy, J., Smith, J. D., Wilson, K. R., Lanz, V. A., Hueglin, C., Sun, Y. L., Tian, J., Laaksonen, A., Raatikainen, T., Rautiainen, J., Vaattovaara, P., Ehn, M., Kulmala, M., Tomlinson, J. M., Collins, D. R., Cubison, M. J., Dunlea, E. J., Huffman, J. A., Onasch, T. B., Alfarra, M. R., Williams, P. I., Bower, K., Kondo, Y., Schneider, J., Drewnick, F., Borrmann, S., Weimer, S., Demerjian, K., Salcedo, D., Cottrell, L., Griffin, R., Takami, A., Miyoshi, T., Hatakeyama, S., Shimono, A., Sun, J. Y., Zhang, Y. M., Dzepina, K., Kimmel, J. R., Sueper, D., Jayne, J. T., Herndon, S. C., Trimborn, A. M., Williams, L. R., Wood, E. C., Kolb, C. E., Middlebrook, A. M., Baltensperger, U., and Worsnop, D. R.: Evolution of organic aerosols in the atmosphere, Science, 326(5959), 1525-1529, doi:10.1126/science.1180353, 2009.

Kalberer, M., Paulsen, D., Sax, M., Steinbacher, M., Dommen, J., Prevot, A. S. H., Fisseha, R., Weingartner, E., Frankevich, V., Zenobi, R., and Baltensperger, U.: Identification of polymers as major components of atmospheric organic aerosols, Science, 303, 1659-1662, 2004.

Kautzman, K. E., Surratt, J. D., Chan, M. N., Chan, A. W. H., Hersey, S. P., Chhabra, P. S., Dalleska, N. F., Wennberg, P. O., 
Flagan, R. C., and Seinfeld, J. H.: Chemical composition of gasand aerosol-phase products from the photooxidation of naphthalene, J. Phys. Chem. A, 114(2), 913-934, doi:1021/jp908530s, 2010.

Keywood, M. D., Kroll, J. H., Varutbangkul, V., Bahreini, R., Flagan, R. C., and Seinfeld, J. H.: Secondary organic aerosol formation from cyclohexene ozonolysis: effect of $\mathrm{OH}$ scavenger and the role of radical chemistry, Environ. Sci. Technol., 38, 33433350, doi:10.1021/Es049725j, 2004.

Kleindienst, T. E., Jaoui, M., Lewandowski, M., Offenberg, J. H., Lewis, C. W., Bhave, P. V., and Edney, E. O.: Estimates of the contributions of biogenic and anthropogenic hydrocarbons to secondary organic aerosol at a southeastern US location, Atmos. Env., 41, 8288-8300, doi:10.1016/j.atmosenv.2007.06.045, 2007.

Kleindienst, T. E., Lewandowski, M., Offenberg, J. H., Jaoui, M., Edney, E. O.: The formation of secondary organic aerosol from the isoprene $+\mathrm{OH}$ reaction in the absence of $\mathrm{NO}_{\mathrm{x}}$, Atmos. Chem. Phys., 9, 6541-6558, 2009,

http://www.atmos-chem-phys.net/9/6541/2009/.

Koch, S., Winterhalter, R., Uherek, E., Kolloff, A., Neeb, P., and Moortgat, G. K.: Formation of new particles in the gas-phase ozonolysis of monoterpenes, Atmos. Environ., 34, 4031-4042, 2000.

Kroll, J. H. and Seinfeld, J. H.: Chemistry of secondary organic aerosol: Formation and evolution of low-volatility organics in the atmosphere, Atmos. Environ., 42, 3593-3624, doi:10.1016/j.atmosenv.2008.01.003, 2008.

Kroll, J. H., Ng, N. L., Murphy, S. M., Flagan, R. C., and Seinfeld, J. H.: Secondary organic aerosol formation from isoprene photooxidation, Environ. Sci. Technol., 40, 1869-1877, doi:10.1021/Es0524301, 2006.

Kroll, J. H., Smith, J. D., Che, D. L., Kessler, S. H., Worsnop, D. R., and Wilson, K. R.: Measurement of fragmentation and functionalization pathways in the heterogeneous oxidation of oxidized organic aerosol, Phys. Chem. Chem. Phys., 11, 8005-8014, doi:10.1039/B905289e, 2009.

Kua, J., Hanley, S. W., and De Haan, D. O.: Thermodynamics and kinetics of glyoxal dimer formation: a computational study, J. Phys. Chem. A, 112, 66-72, doi:10.1021/Jp076573g, 2008.

Lanz, V. A., Alfarra, M. R., Baltensperger, U., Buchmann, B., Hueglin, C., and Prévôt, A. S. H.: Source apportionment of submicron organic aerosols at an urban site by factor analytical modelling of aerosol mass spectra, Atmos. Chem. Phys., 7, 15031522, 2007, http://www.atmos-chem-phys.net/7/1503/2007/.

Lee, M. H., Heikes, B. G., and O'Sullivan, D. W.: Hydrogen peroxide and organic hydroperoxide in the troposphere: a review, Atmos. Environ., 34, 3475-3494, 2000.

Loeffler, K. W., Koehler, C. A., Paul, N. M., and De Haan, D. O.: Oligomer formation in evaporating aqueous glyoxal and methyl glyoxal solutions, Environ. Sci. Technol., 40, 6318-6323, doi:10.1021/Es060810w, 2006.

Malloy, Q. G. J., Li Qi, , Warren, B., Cocker III, D. R., Erupe, M. E., and Silva, P. J.: Secondary organic aerosol formation from primary aliphatic amines with $\mathrm{NO}_{3}$ radical, Atmos. Chem. Phys., 9, 2051-2060, 2009,

http://www.atmos-chem-phys.net/9/2051/2009/.

Mohr, C., Huffman, J. A., Cubison, M. J., Aiken, A. C., Docherty, K. S., Kimmel, J. R., Ulbricht, I. M., Hannigan, M., and Jimenez, J. L.: Characterization of primary organic aerosol emissions from meat cooking, trash burning, and motor vehicles with high-resolution aerosol mass spectrometry and comparison with ambient and chamber observations, Environ. Sci. Technol., 43, 2443-2449, doi:10.1021/Es8011518, 2009.

Ng, N. L., Kroll, J. H., Keywood, M. D., Bahreini, R., Varutbangkul, V., Flagan, R. C., Seinfeld, J. H., Lee, A., and Goldstein, A. H.: Contribution of first- versus second-generation products to secondary organic aerosols formed in the oxidation of biogenic hydrocarbons, Environ. Sci. Technol., 40, 2283-2297, doi:10.1021/Es052269u, 2006.

Ng, N. L., Kroll, J. H., Chan, A. W. H., Chhabra, P. S., Flagan, R. C., and Seinfeld, J. H.: Secondary organic aerosol formation from m-xylene, toluene, and benzene, Atmos. Chem. Phys., 7, 3909-3922, 2007,

http://www.atmos-chem-phys.net/7/3909/2007/. 7.

Reinhardt, A., Emmenegger, C., Gerrits, B., Panse, C., Dommen, J., Baltensperger, U., Zenobi, R., and Kalberer, M.: Ultrahigh mass resolution and accurate mass measurements as a tool to characterize oligomers in secondary organic aerosols, Anal. Chem., 79, 4074-4082, doi:10.1021/Ac062425v, 2007.

Renbaum, L. H. and Smith, G. D.: Organic nitrate formation in the radical-initiated oxidation of model aerosol particles in the presence of $\mathrm{NO}_{\mathrm{x}}$, Phys. Chem. Chem. Phys., 11, 8040-8047, doi:10.1039/B909239k, 2009.

Roberts, J. M. and Fajer, R. W.: Uv absorption cross-sections of organic nitrates of potential atmospheric importance and estimation of atmospheric lifetimes, Environ. Sci. Technol., 23, 945951, 1989.

Rollins, A. W., Fry, J. L., Hunter, J. F., Kroll, J. H., Worsnop, D. R., Singaram, S. W., and Cohen, R. C.: Elemental analysis of aerosol organic nitrates with electron ionization high-resolution mass spectrometry, Atmos. Chem. Phys., 3, 301-310, 2010, http://www.atmos-chem-phys.net/3/301/2010/.

Sato, K.: Detection of nitrooxypolyols in secondary organic aerosol formed from the photooxidation of conjugated dienes under high- $\mathrm{NO}_{\mathrm{x}}$ conditions, Atmos. Environ., 42, 6851-6861, doi:10.1016/j.atmosenv.2008.05.010, 2008.

Sato, K., Hatakeyama, S., and Imamura, T.: Secondary organic aerosol formation during the photooxidation of toluene: $\mathrm{NO}_{\mathrm{x}}$ dependence of chemical composition, J. Phys. Chem. A, 111, 9796-9808, doi:10.1021/Jp071419f, 2007.

Sato, K., Takami, A., Isozaki, T., Hikida, T., Shimono, A., and Imamura, T.: Mass spectrometric study of secondary organic aerosol formed from the photo-oxidation of aromatic hydrocarbons, Atmos. Environ., 44, 1080-1087, doi:10.1016/j.atmosenv.2009.12.013, 2010.

Shilling, J. E., Chen, Q., King, S. M., Rosenoern, T., Kroll, J. H., Worsnop, D. R., DeCarlo, P. F., Aiken, A. C., Sueper, D., Jimenez, J. L., and Martin, S. T.: Loading-dependent elemental composition of $\alpha$-pinene SOA particles, Atmos. Chem. Phys., 9, 771-782, 2009, http://www.atmos-chem-phys.net/9/771/2009/.

Smith, J. D., Kroll, J. H., Cappa, C. D., Che, D. L., Liu, C. L., Ahmed, M., Leone, S. R., Worsnop, D. R., and Wilson, K. R.: The heterogeneous reaction of hydroxyl radicals with submicron squalane particles: a model system for understanding the oxidative aging of ambient aerosols, Atmos. Chem. Phys., 9, 3209-3222, 2009,

http://www.atmos-chem-phys.net/9/3209/2009/. 
Sun, Y., Zhang, Q., Macdonald, A. M., Hayden, K., Li, S. M., Liggio, J., Liu, P. S. K., Anlauf, K. G., Leaitch, W. R., Steffen, A., Cubison, M., Worsnop, D. R., van Donkelaar, A., and Martin, R. V.: Size-resolved aerosol chemistry on Whistler Mountain, Canada with a high-resolution aerosol mass spectrometer during INTEX-B, Atmos. Chem. Phys., 9, 3095-3111, 2009, http://www.atmos-chem-phys.net/9/3095/2009/.

Surratt, J. D., Murphy, S. M., Kroll, J. H., Ng, N. L., Hildebrandt, L., Sorooshian, A., Szmigielski, R., Vermeylen, R., Maenhaut, W., Claeys, M., Flagan, R. C., and Seinfeld, J. H.: Chemical composition of secondary organic aerosol formed from the photooxidation of isoprene, J. Phys. Chem. A, 110, 9665-9690, doi:10.1021/Jp061734m, 2006.

Surratt, J. D., Lewandowski, M., Offenberg, J. H., Jaoui, M., Kleindienst, T. E., Edney, E. O., and Seinfeld, J. H.: Effect of acidity on secondary organic aerosol formation from isoprene, Environ. Sci. Technol., 41, 5363-5369, doi:10.1021/Es0704176, 2007.

Surratt, J. D., Gómez-Gónzalez, Y., Chan, A. W. H., Vermeylen, R., Shahgholi, M., Kleindienst, T. E., Edney, E. O., Offenberg, J. H., Lewandowski, M., Jaoui, M., Maenhaut, W., Claeys, M., Flagan, R. C., and Seinfeld, J. H.: Organosulfate formation in biogenic secondary organic aerosol, J. Phys. Chem. A, 112, 83458378, doi:10.1021/jp802310p, 2008.

Surratt, J. D., Chan, A. W. H., Eddingsaas, N. C., Chan, M. N., Loza, C. L., Kwan, A. J., Hersey, S. P., Flagan, R. C., Wennberg, P. O., and Seinfeld, J. H.: Reactive intermediates revealed in secondary organic aerosol formation from isoprene, Proc. Natl. Acad. Sci., 107(15), 6640-6645, doi10.1073/pnas.0911114107, 2010.

Szmigielski, R., Surratt, J. D., Vermeylen, R., Szmigielska, K., Kroll, J. H., Ng, N. L., Murphy, S. M., Sorooshian, A., Seinfeld, J. H., and Claeys, M.: Characterization of 2-methylglyceric acid oligomers in secondary organic aerosol formed from the photooxidation of isoprene using trimethylsilylation and gas chromatography/ion trap mass spectrometry, J. Mass Spectrom., 42, 101-116, doi:10.1002/Jms.1146, 2007.

Takegawa, N., Miyakawa, T., Kawamura, K., and Kondo, Y.: Contribution of selected dicarboxylic and omega-oxocarboxylic acids in ambient aerosol to the $\mathrm{m} / \mathrm{z}, 44$ signal of an aerodyne aerosol mass spectrometer, Aerosol Sci. Tech., 41, 418-437, doi:10.1080/02786820701203215, 2007.

Tolocka, M. P., Heaton, K. J., Dreyfus, M. A., Wang, S. Y., Zordan, C. A., Saul, T. D., and Johnston, M. V.: Chemistry of particle inception and growth during $\alpha$-pinene ozonolysis, Environ. Sci. Technol., 40, 1843-1848, doi:10.1021/Es051926f, 2006.

Ulbrich, I. M., Canagaratna, M. R., Zhang, Q., Worsnop, D. R., and Jimenez, J. L.: Interpretation of organic components from Positive Matrix Factorization of aerosol mass spectrometric data, Atmos. Chem. Phys., 9, 2891-2918, 2009, http://www.atmos-chem-phys.net/9/2891/2009/.
Volkamer, R., Martini, F. S., Molina, L. T., Salcedo, D., Jimenez, J. L., and Molina, M. J.: A missing sink for gas-phase glyoxal in Mexico City: formation of secondary organic aerosol, Geophys. Res. Lett., 34, L13805, doi:10.1029/2007g1030752, 2007.

Volkamer, R., Ziemann, P. J., and Molina, M. J.: Secondary Organic Aerosol Formation from Acetylene $\left(\mathrm{C}_{2} \mathrm{H}_{2}\right)$ : seed effect on SOA yields due to organic photochemistry in the aerosol aqueous phase, Atmos. Chem. Phys., 9, 1907-1928, 2009, http://www.atmos-chem-phys.net/9/1907/2009/.

Walser, M. L., Desyaterik, Y., Laskin, J., Laskin, A., and Nizkorodov, S. A.: High-resolution mass spectrometric analysis of secondary organic aerosol produced by ozonation of limonene, Phys. Chem. Chem. Phys., 10, 1009-1022, doi:10.1039/B712620d, 2008.

Wang, W., Kourtchev, I., Graham, B., Cafmeyer, J., Maenhaut, W., and Claeys, M.: Characterization of oxygenated derivatives of isoprene related to 2-methyltetrols in Amazonian aerosols using trimethylsilylation and gas chromatography/ion trap mass spectrometry, Rapid Commun. Mass Sp., 19, 13431351, doi:10.1002/Rcm.1940, 2005.

Whipple, E. B.: Structure of glyoxal in water, J. Am. Chem. Soc., 92, 7183, doi:10.1021/ja00727a027, 1970.

Yu, J. Z., Cocker, D. R., Griffin, R. J., Flagan, R. C., and Seinfeld, J. H.: Gas-phase ozone oxidation of monoterpenes: gaseous and particulate products, J. Atmos. Chem., 34, 207-258, 1999.

Zhang, Q., Alfarra, M. R., Worsnop, D. R., Allan, J. D., Coe, H., Canagaratna, M. R., and Jimenez, J. L.: Deconvolution and quantification of hydrocarbon-like and oxygenated organic aerosols based on aerosol mass spectrometry, Environ. Sci. Technol., 39, 4938-4952, doi:10.1021/Es0485681, 2005a.

Zhang, Q., Worsnop, D. R., Canagaratna, M. R., and Jimenez, J. L.: Hydrocarbon-like and oxygenated organic aerosols in Pittsburgh: insights into sources and processes of organic aerosols, Atmos. Chem. Phys., 5, 3289-3311, 2005b,

http://www.atmos-chem-phys.net/5/3289/2005/.

Zhang, Q., Jimenez, J. L., Canagaratna, M. R., Allan, J. D., Coe, H., Ulbrich, I., Alfarra, M. R., Takami, A., Middlebrook, A. M., Sun, Y. L., Dzepina, K., Dunlea, E., Docherty, K., DeCarlo, P. F., Salcedo, D., Onasch, T., Jayne, J. T., Miyoshi, T., Shimono, A., Hatakeyama, S., Takegawa, N., Kondo, Y., Schneider, J., Drewnick, F., Borrmann, S., Weimer, S., Demerjian, K., Williams, P., Bower, K., Bahreini, R., Cottrell, L., Griffin, R. J., Rautiainen, J., Sun, J. Y., Zhang, Y. M., and Worsnop, D. R.: Ubiquity and dominance of oxygenated species in organic aerosols in anthropogenically-influenced Northern Hemisphere midlatitudes, Geophys. Res. Lett., 34, L13801, doi:10.1029/2007g1029979, 2007. 